\title{
Seriality and the Search for Order: Scientific Print and its Problems During the Late Nineteenth Century
}

\section{Citation}

Csiszar, Alex. Seriality and the search for order: scientific print and its problems during the late Nineteenth Century. History of Science 48(3/4): 399-434.

\section{Published Version}

http://www.shpltd.co.uk/hscont48.html

\section{Permanent link}

http://nrs.harvard.edu/urn-3:HUL.InstRepos:5364556

\section{Terms of Use}

This article was downloaded from Harvard University's DASH repository, and is made available under the terms and conditions applicable to Open Access Policy Articles, as set forth at http:// nrs.harvard.edu/urn-3:HUL.InstRepos:dash.current.terms-of-use\#OAP

\section{Share Your Story}

The Harvard community has made this article openly available.

Please share how this access benefits you. Submit a story.

Accessibility 


\section{SERIALITY AND THE SEARCH FOR ORDER: SCIENTIFIC PRINT AND ITS PROBLEMS DURING THE LATE NINETEENTH CENTURY \\ ALEX CSISZAR \\ HARVARD UNIVERSITY}

"I have been hunting every where in vain for Godron", reported Joseph Dalton Hooker to Charles Darwin in March 1855, "I shall not rest till I have ferretted it out". Hooker was referring not to a person, nor to a plant specimen that might have been in the Herbarium at Kew Gardens, but to a mislaid text. ${ }^{1}$ Darwin had sought Hooker's guidance after stumbling on a footnote in a collection of botanical memoirs; it referred to a work called "De l'espèce et des races" by someone named Godron. Such a title alone might have been enough to attract his attention; but the footnote also implied that this work reported on several instances of variations in pear seeds derived from a single parent. Darwin had become intrigued; having worked out a great deal of his theory of natural selection by 1855 , he was keen not only to gather more evidence, but also to gauge the progress of scientific opinion on the variation of species in general, especially as he looked forward to begin drafting his "species book". Darwin jotted down the title in his "Books to be Read" notebook. But before he could read it, Darwin would need to find it. ${ }^{2}$

The techniques and tools scientists have used to seek out and sort scientific information in print comprise a significant, though largely unexplored, domain of practice for historians of modern science. The methods used by Darwin and his contemporaries for locating relevant print sources were - as they would continue to be - varied, complex, and often serendipitous; they might sometimes involve consulting indexes and catalogues, but they also included trawling the contents of serials and titles of monographs on the shelves of personal and institutional libraries, following the trail of footnotes and lists of references, and (perhaps most importantly) corresponding with colleagues, booksellers, and friends for guidance, new leads, and off-the-cuff reviews. But these varied practices have a history as well, one that is closely coupled not only to developments in scientific publishing, but also to the ways that communities of specialists have envisaged the character and material form of the knowledge that they produce and maintain, and even to the organization and sources of authority of these communities themselves.

Over the second half of the nineteenth century countless new publications saw the light of day bibliographical catalogues, abstract journals, Jahresberichte, and nomenclatural indexes - that were designed in part to bring order and efficiency to literary research in the natural sciences. Paradoxically, however, as the century wore on, the increasingly rich field of such aids to research seemed to lead only to increasingly emphatic appeals for better organization and for more efficient access to the published record of science. In Britain and France, these grievances and proposed solutions ultimately reached their zenith during the 1890s. British discontent with the order of information - focused especially on the organization of specialized periodicals - became a matter of heated public deliberation in the pages of Nature and elsewhere. French information entrepreneurs, on the other hand, launched a diverse array of schemes services, bureaus, and publications - in attempts to reinvent the ways in which savants sought out and envisaged scientific information. These developments in their turn heralded the rise of even more ambitious turn-of-the-century enterprises dedicated to assembling universal, minutely-classified, catalogues of scientific knowledge in print.

But late-century enthusiasm for efficient instruments of search was not simply an inevitable reaction to an out-of-control flood of knowledge coming into print, nor did it establish a new era in which researchers at last eliminated their reliance on personal connections and ad hoc methods for learning what is 'known' on a given topic in favour of some more formal or rational system of information retrieval. Much more crucial, I will argue, is that these events were prompted by, and helped to consolidate, a monumental shift whereby scientists increasingly perceived the social and intellectual life of science to be lodged in the pages of the specialized scientific literature, and especially in the expansive terrain of the scientific periodical. This shift was qualitative, rather than quantitative, and it concerned the ascendancy of the journal as the primary media type for representing authoritative scientific knowledge.

In developing this argument, my hope is to open up a Tocquevillian perspective on the history of scientific communication, according to which actors who have demanded dramatic - even revolutionary - 
changes to the status quo, did not necessarily do so as a response to increasingly desperate circumstances, but precisely when piecemeal reforms and improvements made available a partial vision of what a potential ideal future might look like. ${ }^{3}$ Only when scientific knowledge, figured as a landscape of scientific papers, lurched into fractional visibility, did demands for a total, comprehensive vision of this paper landscape take on meaning and urgency. By the end of the century, the organization of scientific serials offered a potential solution to managing and imagining scientific communities themselves.

\section{THE LITERATURE SEARCH AND THE ASCENDANCY OF THE SCIENTIFIC JOURNAL}

When Darwin had set out to find Godron's "De l'espèce et des races" he was not even sure what, exactly, he was looking for. That the original citation had mentioned page numbers suggested that at least this was indeed a printed text (as opposed, for instance, to a lecture) that he was after, but its format remained a mystery: it might have been a full monograph or a smaller single-authored pamphlet, but it might also have appeared in a journal or in some scientific society's transactions, or even in an encyclopedia or some other multi-authored work. The citation had not even included a clear publication

date. ${ }^{4}$ Had he been in London, Darwin might first have tried his luck by visiting the libraries of the Linnean and the Royal Society (both conveniently located at Burlington House). With so little to go on, however, his personal library in Kent - despite Darwin's being an assiduous collector of natural historical publications - did not prove very helpful. As he often did, Darwin consulted booksellers in London, including Williams \& Norgate, who did a big trade in foreign scientific literature. None of them had heard of any such work. Even the booksellers in Paris seemed to know nothing about it. ${ }^{5}$

At the very least, Darwin had reason to believe he was looking for a botanical text. Just as if he were searching for more information on some plant genus, he naturally looked to Kew for enlightenment. His botanical colleagues there, Joseph Hooker and George Bentham, were sure to know what this was about. For his part, Hooker was certain that he had seen and even read it, but could now find no trace. Hooker, as we've seen, also got caught up in the search; he too contacted others, such as John Lindley - the editor of the Gardeners' chronicle and the Botanical register - about it. Despite these efforts, Godron remained elusive. But Darwin, even if slightly embarrassed by the fuss he had stirred up, ${ }^{6}$ was not yet ready to give up the hunt.

The particular text containing the footnote that had launched him on his quest - "The phenomenon of rejuvenescence in nature" - was a translation of a work by the German botanist Alexander Braun; Darwin now reasoned that the original German memoir might contain a more informative citation. But locating the latter presented some of the same problems, and the translation did not even supply the original untranslated title. At least one person in England was bound to know something about it: the translator himself. Darwin dispatched a plea for assistance to Arthur Henfrey, who had produced the English edition of Braun for the Ray Society. Henfrey made a great impression on Darwin by the extensive knowledge of botanical literature evident in his responses, yet not he even he could offer any new leads. Now Darwin conceded defeat: "If you cannot find Godron, it is hopeless [. . . ] I sh $\mathrm{s}^{\mathrm{d}}$. certainly have been very glad to have known what it is about. But I must give it up". ${ }^{7}$ The trail went cold.

Hope revived a few months later, however. In June, Darwin came across a recently-published pamphlet by Godron on the distribution of plants in southern France; he though it a "capital paper" and was "very much interested" in its contents. ${ }^{8}$ Godron turned out to be Dominique Alexandre Godron, a prominent French botanist based in Nancy. And on the second page of this text Godron himself cited what appeared to be the long-sought paper on species: it had appeared in a volume of the Mémoires published by the Académie de Nancy sometime in 1848-49. Darwin at last had a reference by which to work. But getting hold of the transactions of a provincial French academy was still no straightforward matter. Despite renewed effort, including finally checking the libraries of the Linnean and the Royal Society and again having Hooker check the library at Kew, it appears that Darwin never did lay eyes on Godron's paper. ${ }^{9}$

Ultimately, he didn't have to; he simply waited for the book. In 1859, a two-volume monograph by Godron appeared, titled De l'espèce et des races dans les êtres organisés et spécialement de l'unité de l'espèce humaine, incorporating updated versions of his earlier papers on this subject. Put out by Baillière 
et fils, a prominent medical publishing firm based in Paris (with a London bureau that Darwin frequented), it was easy to find, though it appeared just too late to be useful to the author of On the origin of species. Darwin read through its two volumes in spring of 1860, but after all that bother he was a little bit disappointed. Godron's views were more commonplace than Darwin had hoped, although he did put "the old case well that mere physical conditions do very little in modifying organic forms". ${ }^{10}$ Darwin later made extensive use of Godron's book for his more comprehensive - and exhaustively-footnoted - monograph on The variation of animals and plants under domestication, first published in 1868.

Reflecting on his misadventure in literary research, Darwin observed, "How useful a parallel book to Agassiz \& Stricklands Zoolog Bibliography would be in Botany!" The Bibliographia zoologiae, whose final volume had just appeared in 1854, was a four-volume work that contained bibliographical details on a vast range of zoological and geological publications across an equally vast period of time. ${ }^{11}$ But in this case, a botanical equivalent might not have helped much. Bibliographical notices of Godron's essay that had appeared, such as the one in the Académie des Sciences's Comptes rendus in 1848, ${ }^{12}$ failed even to indicate the periodical in which it had been published. There was good reason for this: it is likely that neither the editors of the Comptes rendus nor Braun (the author who had originally cited this work) had ever seen the Mémoires of Nancy at all. In the spring of 1848, Godron - knowing better than to trust the circulation of a provincial academy's transactions - had distributed separate copies of his paper; following a practice that was routine for such tirages à part, these copies suppressed nearly every trace of their being excerpts: they came with their own title page, they were repaginated, and the only clue that they formed a part of a larger multi-authored volume was an easy-to-miss parenthetical note on the final page of text: "(Extrait des Mémoires de la Société des Sciences, Lettres et Arts de Nancy, pour l'année 1847)." The citations in the Comptes rendus and in Braun ${ }^{13}$ were to this single-authored pamphlet, to possess a copy of which likely entailed having been sent one by the author himself.

The bewildering array of forms in which Godron's text circulated - as part of a serial publication, as single-authored pamphlet distributed through personal correspondence, and as a component of a larger monograph - and Darwin's multiform, though not very successful, strategies for tracking it down including library searches, bookseller consultations, and personal appeals for assistance - is emblematic of the heterogeneity and complexity of the information order in which they and their peers operated.

Over the second half of the nineteenth century, many aspects of scientists' informational worlds would only continue to become even more complex and varied. On at least one crucial front, however, there was significant consolidation: the specialized scientific periodical was slowly pushing out other formats to become recognized as the dominant genre for representing both the cumulative and the present state of knowledge possessed by the scientific community. By the twentieth century, it went without saying that for scientists to establish their credentials it was necessary not simply to make their findings public, but to publish them in authoritative scientific journals. Information scientists and hiring committees came to use the scientific paper as the basic unit by which to measure and evaluate scientific productivity and scientific careers. ${ }^{14}$ The peer-reviewed scientific journal had achieved a virtual monopoly on expert scientific authorship.

But that periodicals should constitute the most authoritative sites for the registration of knowledge claims would have puzzled men of science even well into the nineteenth century. When learned journals had first emerged in the seventeenth century, they would have been among the last places to look to find authoritative knowledge claims. They took after newspapers and gazettes, which were by their nature ephemeral and were often in disrepute. As news of the republic of letters, they included book reviews, reports of goings-on, and digests and excerpts of correspondence. Far from being a venue for establishing new knowledge, the learned journal was itself a novel solution to there being too much of it: the journalist's role was that of monitoring, selecting from, arranging, and summarizing, the continuous flood of new books and other news making its way through the republic of letters.

By the mid-nineteenth century the authoritative scientific journal had come into being, but it remained just one element in a wide-ranging mixed economy of formats for authoritative scientific publication, also including monographs, pamphlets, collections, encyclopedias, and a diverse array of periodical genres aimed at non-specialist audiences. Godron's paper had only ambiguously been from a 
periodical at all: savants routinely distinguished the memoirs and transactions of learned societies, which typically appeared at irregular and infrequent intervals, and which tended to contain more polished, often peer-reviewed, texts, from the faster-paced, and arguably less-authoritative, periodicals put out by commercial publishers. Only during the 1830s did many learned societies in Britain and France begin to publish periodical proceedings or journals. This turn to seriality had taken place after major bodies such as the Royal Society and the Académie des Sciences had found themselves forced to compete for authority and for content with the raft of new commercial periodicals - which published original, authored research papers - that had been appearing since the late eighteenth century. ${ }^{15}$ Memoirs such as Godron's normally circulated as single-authored pamphlets prior to the publication of the volumes in which they were scheduled to appear, ${ }^{16}$ and they often gave little or no indication of their association with the latter. This was sometimes because the precise shape and date of the projected volume was yet to be determined, but it was also because a single-authored publication might seem to confer greater prestige on an author than publications that were contained in larger multi-authored works. ${ }^{17}$ As late as 1867 , the Cambridge physiologist Michael Foster could refer to a scientist's papers published here and there as "specimens of those broken pieces of fact, which every scientific worker throws out to the world, hoping that on them, some time or other, some truth may come to land" ${ }^{18}$ Darwin had simply needed to be patient; eventually, anything of lasting value that Godron had written would surely be incorporated into a synthetic, definitive, monograph. Periodicals were okay for new facts; but durable claims to Truth remained the territory of books.

Conversely, men of science, particularly in Britain, could still treat informal correspondence and oral communications as sufficient in themselves for publicizing knowledge claims and for establishing priority. ${ }^{19}$ When in 1846 the French awarded credit to the astronomer Urbain Le Verrier for having predicted the existence of the planet Neptune in the pages of the Comptes rendus hebdomadaires, British astronomers responded by supporting their own contender for the discovery, John Couch Adams. Although Adams had published nothing on the subject, they cited the paper trail of written correspondence between him and other British astronomers, and pointed out that his own prediction had "been a subject of common conversation among [his personal friends] for the last two years". ${ }^{20}$ François Arago, representing the French case, responded that the only "rational and just way to write the history of science is to rely exclusively on publications having a precise date" - all else being "confusion and obscurity". But declarations such as this were no reliable description of the accepted rules of scientific propriety; they remained arguments deployed for specific ends, and they were frequently matched by equally forceful rebuttals. ${ }^{21}$

But over the course of the century, claims such as Arago's that print offered the most durable foundation for registering scientific knowledge progressively became more credible, and at the same time specialized serials increasingly came to form the solid core of science in print. It is not simply that there were more of them, churning out more articles and covering an ever-more-minute division of branches of knowledge; rather, this shift represented a sea change in the kinds of genres that were deemed most suitable and trustworthy for the publication of original authored contributions to knowledge. In addition to circulating information about new discoveries, scientific periodicals were increasingly the de jure site for staking and adjudicating priority claims, and they were increasingly seen as constituting the primary record of scientific advance. Savants were finding less call to consolidate their most important periodical contributions by authoring broader, synthetic, monographs. By 1902 Foster could assert that "when a man of science writes a book, he writes, as a rule, either a textbook, in which original matter is out of place or even dangerous, or a lengthened essay in which he developes general views at a greater length than he is at liberty to do in a periodical". Darwin himself, who had "embodied the results of long years of observation and reflection in a series of books", had already been an exceptional case. The example of Thomas Henry Huxley corresponded better to the new norm: "Nearly all his important contributions to science were published in periodicals [...] To judge of Huxley's worth as an investigator, one must go to his "collected papers"; the books he wrote were either "textbooks, $[. .$.$] or more or less polemical essays". { }^{22}$ And, while informal correspondence and conversation remained as crucial as ever to scientific intercourse, the idea that print publication represented the most immutable and mobile vehicle for authoritative knowledge continued to gain ground. The continued primacy of personal networks for the circulation of scientific information 
was increasingly viewed with suspicion by reformers looking to remodel science as a more rational, professional, and international enterprise.

But the ascendancy of the specialized periodical was not the triumph of certainty and rationality that some twentieth-century observers portrayed it as. ${ }^{23}$ Not only was its slow rise contingent and bitterly contested, but its apparent dominance by the end of the century had seemed to bring with it a host of new problems. In the words of the British Museum bibliographer Frank Campbell, "the development of Periodical Literature has been such as to constitute a very considerable danger to the progress of knowledge". ${ }^{24}$ The rise of the scientific periodical raised not only practical but also symbolic questions about whether the vast, dispersed assortment of specialized serials could be trusted to all the uses they were now being put to, whether new synthesizing genres might be required to supplement these publications, and even whether scientific publishing practices should be re-engineered from the ground up. ${ }^{25}$

As a practical matter, the quantity of new publication turned out to be less compelling than concerns about dispersion and specialization. As an anonymous piece in Nature put it in 1883, men of science "naturally grumble at the constant increase in the number of journals, Proceedings, Transactions, \&c., which they must painfully look over. But this increase is inevitable. What we should aim at is not its curtailment so much as its methodical arrangement". ${ }^{26}$ For the scientific imaginary, print seriality posed a challenge, but also opened new space, for re-envisaging the unity and general character of the scientific enterprise. Confidence in the intelligibility and accessibility of nature had long derived support from the image of Nature as a Book. Although the trope had many variations, the Book of Nature was generally single-authored and bounded (with a logical beginning and end), and treated subjects in a cohesive, comprehensive manner. ${ }^{27}$ But as James Clerk Maxwell playfully suggested in 1856, little of this followed if nature were imagined instead as a magazine. The idea turned out to be prescient; subsequent observers, such as Hermann von Helmholtz and Lord Rayleigh, routinely mingled their reflections on the problem of combining isolated scientific facts into theoretical unities with their reflections on the problem of organizing scientific papers via more comprehensive synthetic genres. By 1900, the mathematician and physicist Henri Poincaré was deploying a vision of science in which nature was no longer a single bound book at all but instead was figured as a vast expanse of print matter, a body the scientist did not so much read through, as search, select from, and catalogue. ${ }^{28}$

Poincaré's figure came on the heels of a great deal of activity among zoologists, physicists, and others aimed at reforming the publications and institutions concerned with the organization of scientific print. A number of new catalogues and genres for abstracting scientific knowledge appeared over the last decades of the century in tandem with the rising tide of complaints about the disorders brought on by the ascendancy of scientific serials. While worries about the organization of print went back to the early years of the printing press, the sustained attention that natural scientists themselves were now dedicating to this question, across several disciplines, was remarkable. By 1896, dialogue began to align along the gap separating two particularly ambitious enterprises. A number of international conferences under the aegis of the Royal Society beginning that year led to the founding of the International Catalogue of Scientific Literature, a multi-national organization for the production of bibliographical information in seventeen branches of knowledge. Its principal rival, the Institut International de Bibliographie, established in Brussels in 1895 by the socialist internationalists Paul Otlet and Henri La Fontaine, was a federation of associations that set itself the monumental goal of organizing all of the world's published intellectual output. ${ }^{29}$ These enterprises would exercise a profound influence on twentieth-century practices of information retrieval and formal search methodology. In the rest of this essay, however, I will focus on some of the laments, proposals, and schemes in the midst of which these two vast, utopian projects emerged.

A central theme in what follows is that developments in the general periodical press represented a crucial source both of problems and of possible solutions for those concerned with specialist publishing practices in the sciences. On the one hand, the massive growth and diversification of serialized print genres was a constant reminder that, to the chagrin of specialists interested in delineating trustworthy spaces for expert communication, any supposed boundary between specialist and generalist periodicals remained unstable at best. On the other hand, novel institutions and technologies of the mass press - such as lending 
libraries, press clipping services, and bibliographical publications - offered new models for managing and harnessing the power of specialized scientific print. The mass press was a constantly shifting field of both hazards and opportunities for scientific communication.

\section{“THE MACHINERY OF SCIENTIFIC PERIODICALS"}

By a fiction as remarkable as any to be found in law, what has once been published . . . is usually spoken of as 'known', and it is often forgotten that the rediscovery in the library may be a more difficult and uncertain process than the first discovery in the laboratory.

Lord Rayleigh, Presidential Address to the British Association (1884)

In May 1892, a pamphlet appeared in London bookshops titled On the organisation of science (being an essay towards systematisation). It advocated a radical reform of the publishing apparatuses of scientific societies - "the machinery of scientific periodicals" - in the direction of dramatically enhanced centralization and rationalization. The pamphlet was reviewed extensively in the British scientific press, and an already steadily growing murmur of discontent among British men of science over the state of scientific publishing became amplified by several degrees. Its pseudonymous author, "A Free Lance", had struck a nerve. ' $S$ cientific literature' was for the next several years the subject of an ever-expanding laundry list of unflattering depictions - in such terms as chaos and disorder, ${ }^{31}$ uncontrolled dispersion and growth, ${ }^{32}$ wasted and inaccessible resources, and undisciplined authorship. ${ }^{33}$

Much of this was scarcely new; alarm over the "infinite multiplicity of publication" ${ }^{34}$ had been a conventional lament since at least the seventeenth century. ${ }^{35}$ Even the images that men of science were using to describe their frustration - "indigestion", "flood", "chaos" - often had early modern precedents. ${ }^{36}$ If looked at sufficiently close up, however, every period's experience of information indigestion has its own historical specificity. As I suggested earlier, the late-Victorian species of this phenomenon was deeply rooted in the all-embracing role that the scientific periodical had come to play. This, combined with the increasing significance of print as a locus for safeguarding and assessing scientific authority, meant that the general problem of the organization of science, a matter that had historically been associated especially with the organization of scientific societies (especially in Britain, but to varying degrees elsewhere as well), was now tantamount to the problem of the organization of scientific periodicals.

Just as crucially, now that specialization was accepted as an essential (if fraught) aspect of scientific life, the sheer bulk of new publications - notwithstanding the continued attraction of the imagery of hordes and inundations - was not the principal concern of serious reformers. Few found it disturbing that they could not hope to keep up with the progress of knowledge in general. But if what was 'known' was, as Lord Rayleigh implied, imagined to be nearly identical to what was 'published', then the crucial danger that seemed to require solution - one that, I will argue, was both epistemological and social - became that of the searchability of the literature. As I argued above, the literature search could and did take many forms, but now one problem stood above all others in the concerns of men of science: "There is", announced Michael Foster in 1894, "a very pressing need of some easy machinery by means of which an inquirer may discover the existence and learn the exact date and position in literature of the papers which have been published on the subject upon which he is working". ${ }^{37}$

How was an investigator who wished to confirm that a new fact, object, or theory he hoped to publish about had not already been discovered and published by a previous man of science, actually to do so? How was he to rediscover just what was 'known'? With its many annuals, catalogues, and nomenclators, no branch of science had gone further towards solving this problem than zoology, and yet it was precisely zoologists who immediately took the lead in the growing tempest over the disorderly state of scientific publishing. Their central concern was the iconic plight of the systematist who, upon discovering and describing what seemed to be an unknown species, would need to confirm that it really was $n e w^{38}$ Prior to bestowing upon it a name and publishing his description, the zoologist was duty-bound, in order to avoid contributing to nomenclatural disorder or robbing a previous researcher of credit, to embark on a literature search. ${ }^{39}$ 
Where to begin? The most crucial and authoritative sources were periodicals, "the truest representations of the living thought of the day". " But consulting all of the potentially relevant periodicals directly was likely to prove overwhelming: "If anyone wish to realise the situation, let him - since object lessons are more striking than verbal description - pay a visit to the Linnean Society's reading room, and spend ten minutes in wandering through the wilderness of periodical literature set out on the tables. ${ }^{41}$ It would mean consulting the contents not only of the specialized journals connected with zoology, but also the transactions, and perhaps also the proceedings, of national, local, and specialist societies, and possibly even non-specialist journals. Most of the important periodicals did at least possess annual indexes (a venerable custom that had been inaugurated by Henry Oldenburg with the completion of the first volume of the Philosophical transactions in 1666), but most agreed that some still more directed way in was usually required: "Think of the literature that a scientific worker has to read through before he can know what has been done by others-journals, weekly, monthly, yearly, in all languages, journals upon all subjects!" 42 One crucial strategy was simply to ask the advice of those most likely to be familiar with the field in question; Charles Darwin, as we saw, had been able to put a vast network of correspondents to work on his own literature searches. But Darwin was an incredibly well-connected scientist; most investigators, especially those who were younger or on the margins, might not have such a wide circle of correspondents to draw on. ${ }^{43}$ And even Darwin had urged that some more systematic guides to the literature were wanted.

As long as single-authored books had remained a focus of scientific publication, bibliographical works in the sciences had remained continuous with long-standing traditions of systematic bibliography and of booksellers' catalogues. ${ }^{44}$ Systematic digests of the periodical literature, however, were barely in their infancy in the mid-nineteenth century. Over time, as more specialized periodicals were founded whose subjects divided and then clustered around overlapping subjects, commercial journals increasingly provided current listings and summaries not only of relevant new books, but also of the contents of other journals or transactions. The proceedings that scientific societies in Britain and France themselves began to publish in earnest beginning in the 1830s were usually modelled on the reports and summaries of their activities that had already been appearing in commercial periodicals since the first decades of the new century. More comprehensive bibliographies progressively developed a life of their own as stand-alone publications, and some of these even began to arrange their contents via some rational ordering of the subjects they treated. One early current guide to scientific publications that included periodical works was the Pharmaceutisches Central-Blatt (founded in 1830, and renamed the Chemisches Central-Blatt in 1856); many more were founded in the second half of the century, including the Zoological record (1870), the Bulletin des sciences mathématiques et astronomiques (1870), and the Beiblätter zu den Annalen der Physik und Chemie (1877). It was German publications - especially the Jahresberichte, yearly reports focused on a particular discipline that included abstracts, lists of publications, and sometimes review articles - that particularly dominated the field of these new synthetic genres. But that the finest vistas of the scientific landscape should come from a German perspective was a source of unease for men of science in France and Britain; not only was this likely to be a source of national bias, but bibliographical dominance itself seemed to them one more sign - especially in the wake of Germany's resounding victory in the Franco-Prussian War - of their own scientific and industrial decline. ${ }^{45}$

But zoologists in Britain might still have had more reason to be sanguine than other British scientists. The Bibliographia zoologiae et geologiae (1848-54), to which Darwin referred earlier, had been a pioneering work. And the Zoological record, since 1886 published under the auspices of the London Zoological Society, was the best annual guide to zoological papers with a focus on systematics available anywhere; although the quality and format of its various sections was notoriously uneven, many of its listings included abstracts as well. The journals and abstracts published by the Linnean Society were another major source of information and were near at hand for many British naturalists. However, these volumes were avowedly incomplete, and biased toward English work. ${ }^{46}$ Abroad, there was the Zoologischer Jahresbericht (1879-), published by the Naples Stazione Zoologica, which included short abstracts in German under broad subject headings. The Zoologischer Anzeiger also included a Litteratur section that listed articles according to a loose classification of subjects. But access to these expensive publications likely required being near some urban centre, and likely involved a trip to one, if not several, 
libraries. And, as none of them was the result of significantly international collaboration, the zoologist in search of all that was known on a given topic might also feel compelled to consult the various national indexes to scientific literature that were springing up. The French Ministry of Public Instruction, for instance, had begun issuing a Revue des travaux scientifiques in 1881; this collected summaries of books and articles appearing in specialized French publications. But a desire to be entirely thorough could also entail checking the more general periodical literature as well. This was hardly practicable, but some foothold - at least for some of the more important Anglo-American periodicals - might be achieved by consulting the volumes of Poole's Index to periodical literature, a pioneering index of non-specialized periodical works that had been relaunched in collaboration with the American Library Association in 1882.

Zoologists still lamented that none of the search tools on offer could provide them with confidence that they had done their full duty in searching the literature. The crustacean specialist T. R. R. Stebbing predicted that a conscientious naturalist might soon find "his studies in a manner divorced from nature. There is so much to read that little time is left for observing". Without some comprehensive index, warned T. D. A. Cockerell, "nearly the whole lives of zoologists will come to be spent in libraries, until the thing gets so intolerable that some one suggests that we burn all the books, and start afresh from nature".

Stebbing put his finger on the crux of the problem: "there is no limit to the media of publication which may lawfully be employed" to record new zoological information. ${ }^{47}$ Aspirations to searching the literature completely, required, in practice, knowing just where the limits to authoritative scientific publication lay. Catalogues that covered a particular field, some nation's literature, or a particular group of learned societies were multiplying, but none had done very much to illuminate the outer limits of the landscape of scientific print.

The major nineteenth-century effort to establish such limits, and a dramatic sign of the growing significance of specialized periodicals, was the Royal Society's launch of the Catalogue of scientific papers in the 1860s. Following the report of a British Association Committee in 1856 that advocated the production of a book catalogue of scientific memoirs scattered throughout the transactions of learned societies, the Council of the Royal Society had resolved to pursue the project on its own. It expanded the original plan - which was to deal only with the physical and mathematical sciences - to cover all the natural sciences, and it committed to extending the Catalogue's reach to the whole of the nineteenth century. ${ }^{48}$

The Catalogue (Figures 1(a) and 1(b)) was an index arranged by authors' names that was to embrace all papers containing "scientific matter" published since 1800. Perhaps its most crucial feature was that its editors chose to index not only the memoirs that had appeared in the publications of scientific societies (the traditional loci of authoritative scientific publication), but also the scientific papers that had appeared in what they deemed authoritative-enough commercial journals. The explicit aim was for the Catalogue to be complete, but this was to be achieved by defining limits on what papers would count as genuine contributions to science. Newspapers were left out, as were most periodicals focused on popularization or education, not to mention those focused on technical, professional, or medical subjects (save for when they contained papers that were deemed by the editors to touch on some scientific specialization). The Catalogue was thus an exercise in imposing the characteristics of the fledgling genre of the specialized scientific paper - that is to say an authored, original contribution to science with a fixed publication date, regardless of whether it had been published by a learned society or commercial press retroactively backwards onto the rest of the century. ${ }^{49}$ This was by no means a straight-forward task. Not only did it mean determining the outer limits to authoritative scientific venues, but, since many contributions to scientific periodicals did not identify their authors, or did so only partially, the Catalogue's editors had been required to undertake a great deal of investigative labour - contacting authors, editors, and publishers - to reunite such works with the authors to whom they rightfully belonged. 
C A T A LOOG UE

oF

\section{SCIENTIFIC PAPERS.}

$(1800-1863$.

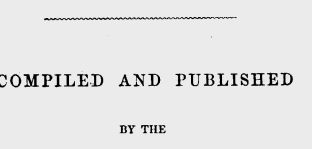

ROYAL SOCIETY OF LONDON.

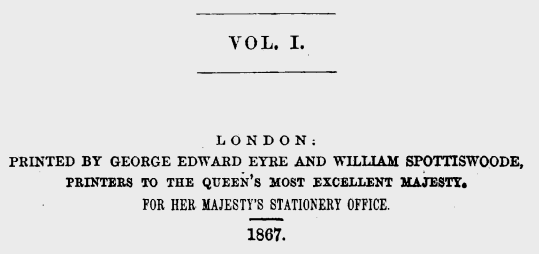

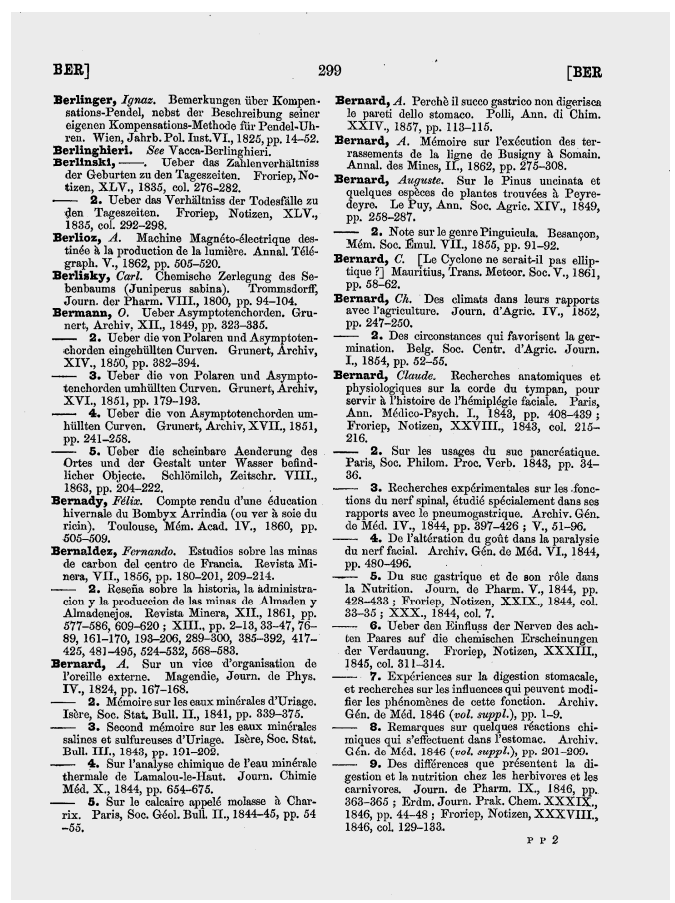

Fig. 1. (a) Cover, and (b) sample page, of the first volume of the Royal Society's Catalogue of scientific papers (f. 1867).

The arrangement by authors' names meant that the Catalogue was most helpful to users that knew who had published on the topic that they were researching. (Had such a publication existed when Darwin was searching for Godron's elusive paper, it might have saved him a good deal of effort. ${ }^{50}$ ) Still, scientists generally reported finding the author-based arrangement helpful even for subject searches, for they often did know the names of the handful of authors most likely to have dealt with the topics they were interested in. Nevertheless, while the Catalogue did have an effect in delineating who counted as a scientific author (the arrangement by authors made possible for the first time the production of a numerical measure of any investigator's worth by counting the number of scientific papers he had published), its lack of a subjectindex still rendered the Catalogue relatively ineffective for the kind of systematic literature search that a zoologist on the lookout for recent species descriptions might wish to mount. ${ }^{51}$

In natural history disciplines more generally, the problem of efficient subject access to the literature was increasingly the focus of cataloguing endeavours. The major consideration zoologists had in view was the scourge of synonymy, whereby species were constantly being renamed by new discoverers, not simply because of bad etiquette, but because there were few systematic means of ascertaining prior discovery. ${ }^{52}$ Since systematic zoology was only as reliable as its taxonomic system, problems of communication did not simply retard progress or lead to disputes over the distribution of credit, but seemed to threaten the order and integrity of knowledge itself. ${ }^{53}$ But the close connection zoologists perceived between print and nomenclatural order was not itself inevitable; it too had a particular history. The first attempt at a standard code for fixing zoological nomenclature, produced by a British Association committee in 1842, had set a precedent by making print publication, preferably in periodicals, crucial to implementing its most hallowed principle, the 'Law of Priority': "MS names have no authority [...] Nor can any unpublished descriptions, however exact... claim any right of priority till published, and then only from the date of their publication." ${ }^{54}$ Attempts to legislate an essential connection between print and priority meant that even universal agreement on a code of nomenclature (the first zoological code claiming international reach was established in 1895) would be abstract nonsense without literary search tools to provide the infrastructure in which they could operate. Ideally, catalogues of natural history publications would work in tandem with catalogues of published species names. Darwin himself, who complained to Hooker of "the difficulties he had experienced in accurately designating the many plants which he had studied", had bequeathed a large 
sum for the production of a catalogue of published names of flowering plants; Hooker used it to launch the Index Kewensis during the $1880 \mathrm{~s} .{ }^{55}$ While such species catalogues themselves have a longer history, a distinguishing feature of the new generation of publications such as the Index Kewensis was that each species was now attached not only to its author, but to a reference to the literature as well, so that these catalogues came to resemble bibliographical tools themselves.

For all these reasons, zoologists potentially had available to them more search tools than they were willing even to make use of on a regular basis. ${ }^{56}$ On the other side of the spectrum, men of science in disciplines such as physics could argue that their situation was rather worse. Following the zoologists' lead, physicists began deliberating in earnest on their own perceived publication problems in 1893. The Physical Society - the principal body representing British physicists - was not as well established as its equivalents in disciplines such as chemistry or zoology, and no group had yet developed systematic procedures for digesting information. ${ }^{57}$ At the British Association meeting in Nottingham that September, a highly anticipated discussion on the publication of physical papers took place on the final day of Section A (Mathematical and Physical Science). To mark the occasion, a local bookseller advertised that it would have copies of A Free Lance's pamphlet On the organisation of science available for purchase. The event commenced with the reading of a paper by the mathematician A. B. Basset laying out the key problems; the subsequent discussion included Lord Rayleigh, George Fitzgerald, James Swinburne, Arthur Rücker, and George Carey Foster. Swinburne characterized "the present system of publishing physical papers as being about as bad as it could be", while others debated the relative merits of a comprehensive index, a cooperative abstracting service, or some more radical plan to centralize the publication of physical papers. ${ }^{58}$ Many physicists noted that practically the only useful synthetic publication for physicists then on offer was the Beiblätter to the German Annalen der Physik und Chemie, which had begun abstracting physics articles in 1877 . The problem was that any reference journal published on the continent came with potential problems of access, barriers of language, and important gaps in coverage of British publications. ${ }^{59}$ There was simply no central listing of physical papers that could make any claim to being 'complete' or reliable; the end result, according to Swinburne, was that the "English physicist [...] has no simple means of following the progress of his own special study". ${ }^{60}$ The lack of an adequate synthetic record led Oliver Lodge to complain that "mere printing in a half-known local journal is not proper publication at all; it is 'printing for private circulation"'. Physical access to journals was also a potential problem; researchers testified that they often relied on whatever abstracts happened to be published in domestic periodicals, not simply to find out about papers, but as a necessary substitute for reading the papers themselves. ${ }^{61} \mathrm{~A}$ "would-be reader of original memoirs and researches", the physicist Silvanus P. Thompson had noted back in 1883, was "compelled to journey from one shore of England to the other in order to consult the Edinburgh Transactions, the Cambridge Transactions, the Comptes Rendus, the volumes of Poggendorf's Annalen, and those of the Annales de Chimie et de Physique, or the memoirs of any one of the five great Academies of the European Continent". ${ }^{62}$

The converse problem, that of authors in search of interested and knowledgeable readers, was just as precarious: "There is no complaint more frequently heard abroad than that important papers of English scientific men are almost inaccessible to the foreigner, because it has been the fashion to communicate them to local societies." ${ }^{63}$ But even when the problem was restricted to circulation within Britain itself, publishing with a view simultaneously to maximizing exposure as well as prestige presented a series of dilemmas. Having abandoned the literature search and composed a possibly career-making paper, a zoological author, for instance, would be confronted with the problem of where to submit it. Surely the most prestigious British periodical venue was the Royal Society's Philosophical transactions. Paradoxically, however, unless the author were a recognized star, observers testified that publishing in the Transactions might severely hamper its coming into the hands of those readers who were in the best position to recognize the paper's significance. Specialists in several disciplines noted that they did not keep regular tabs on new issues of the Transactions since the bulk of the material in any one issue was neither relevant nor comprehensible to them, and its lavish quartos were not only expensive but inconvenient to consult. ${ }^{64} \mathrm{~A}$ better bet for a zoological or botanical author in search of competent readers would be to publish in one of the journals of the Linnean Society. But few bent on professional advancement - an 
increasingly relevant concern by the late nineteenth century, especially once where and how much one had published became just as important as what one had discovered - would wish to forego the prestige that might come with a paper appearing in the Transactions if the opportunity presented itself. The desire to reach interested readers thus seemed at times to come in direct conflict with establishing professional credentials. $^{65}$

The most crucial workaround to these publishing dilemmas was to take personal responsibility for distribution; failure to do so was to risk consigning one's work to oblivion: "Unless the author distributes lavishly separate copies of his paper in every quarter where he considers it important that it should be read, it will pass unnoticed" ${ }^{66}$ The circulation of the memoirs contained in each issue of the Philosophical transactions, for instance, seemed to depend "largely on presentation copies". ${ }^{67}$ In fact, distributing separate copies of memoirs that also appeared as a part of multi-authored volumes had been an important feature of scientific communication since at least the late eighteenth century. But as periodicals replaced monographs as the accepted standard for publishing authoritative work, savants came to see this practice in a new light, so much so that a new term seemed to be required for the format: "In these days when so much original work first sees the light in the pages of scientific periodicals or in the Transactions of Societies, and when such payment as the author receives often consists solely of a few copies of his paper separately printed off for distribution among his friends or fellow workers, the want is felt of an English word to designate such private impressions." The term eventually settled on was 'offprint', which, in its analogy to 'offshoot', emphasized the primacy and priority of the serialized version. ${ }^{68}$ (In contrast, the long-standing English terms used - 'separate papers' or 'separate copies' - could apply both to extracts and to true singleauthored pamphlets.) The crucial role that such copies played in the circulation of knowledge now gave scientists some pause. At its extreme, the distribution function of publishers threatened to reduce to their role in supplying pamphlets for authors to exchange through private circulation. This was a situation that bore an uncomfortable resemblance to earlier epochs of scientific communication, and it was certainly a matter of concern for publishers looking to maximize their paying subscribers. Commercial journals were particularly careful to keep separate copies to a minimum, and often discouraged their early distribution by authors. Taylor \& Francis, publishers of the Philosophical magazine - the premier physics journal in Britain - did not supply authors with gratis separate copies at all. ${ }^{69}$ Offprint circulation was an especially contentious issue in the case of well-known contributors whom editors counted on to draw in subscribers. Delicate negotiations were sometimes required. The editor of Acta mathematica, a mathematics journal with international ambitions that had been launched in Sweden in 1882, was loath to send its star contributor, Henri Poincaré, the separate copies that he desired in a timely manner. ${ }^{70}$ Poincaré, keen on distributing his work to the people that really mattered to him, put the case as follows: "if authors are generally impatient to have their separate copies, it is not in order to distribute numerous copies to all of their friends, but rather to send, as quickly as possible, a copy to ten or so important names [grands noms] whom they desire should know about their work." He argued that distributing a limited number of separate copies would actually "serve as an advertisement for the journal". Editors were, however, understandably wary of such reasoning. ${ }^{71}$

The hazy status of separate copies also had the potential to wreak havoc on the ability of investigators to carry out systematic literature searches (this was in part what had foiled Darwin in 1855). Thus, a repeated demand in publishing reform proposals during the 1890s was for standard formatting that would make perfectly clear the precise serial origins - title, volume, date, page numbers - of all excerpted pamphlets. The traditional objection that this was not possible for societies whose transactions only appeared at irregular intervals was subject to much derision: "In brief, the argument is: 'We are too poor to publish properly; therefore, we must allow authors to publish improperly." ${ }^{, 72}$ Both practically and symbolically, the private correspondence networks that supported the circulation of offprints constituted a microcosm of all that needed to be changed about modern scientific publishing.

What was needed more generally, many agreed, were better standards and protocols - in a word, better 'machinery'. This was the abiding theme of the pamphlet with which A Free Lance had incited the passions of men of science in 1892: "Just as our machinery of local government has become a network of absurdities involving pecuniary waste and administrative inefficiency", he wrote, "so, too, in the machinery 
of science we have a parcel of separate and mutually independent agencies...now all flourishing side by side, to their mutual detriment". His own proposed remedy had been particularly radical. A Free Lance advocated a radical centralization of the "machinery of science" that would see most periodicals eliminated, and scientific societies (whose main raison d'être, according to A Free Lance, had become to publish their journals) coordinated. One of his followers summarized the idea as follows: "in each country each subdivision of science should have its one central and accredited journal in which all papers on that subject worthy of publication should be published" ${ }^{73}$ Thus, for example, the Physical Society of London would be the only legitimate publishing body for physics papers in Britain; all other societies publishing papers on physical topics would subordinate their own publishing efforts to it, while regional non-specialized scientific societies would cease to exist as independent entities. Radical as the program was, versions of it came to be espoused by more powerful figures. Michael Foster, the senior secretary of the Royal Society, agreed with its general outlines; such centralization, he reasoned, was required for the purposes of enforcing stricter and more uniform authorial discipline, for in the current situation, "a great deal of work is thrust upon the world...a veritable sewage thrown into the pure stream of science, which has to be got rid of before the stream can again become free from impurity". ${ }^{74}$

The special position of the Royal Society in this was crucial. Although its international reputation had long been based on its association with the Philosophical transactions, the latter had come in for particularly harsh criticism due to its bulk, its expense, and the charge that it lured authors away from publishing papers that, by rights and for the general welfare of science, belonged in the specialized societies' periodicals. ${ }^{75}$ Once upon a time, the Royal Society had plausibly held a monopoly as a repository of scientific knowledge, so that "men knew where to look for all that was new". ${ }^{76}$ But, as Foster himself admitted, "the development of the several special scientific societies, and of several independent scientific periodicals, has entirely changed the circumstances under which the Society's publications and meetings were instituted" ${ }^{77}$ One possible solution was for the Royal Society to get out of the business of publishing original work altogether and reinvest its energies and substantial publications budget in becoming a third party manager of scientific information. After all, the Royal Society had already taken its first steps toward becoming such a "universal bibliographer" when it inaugurated the Catalogue of scientific papers in midcentury. ${ }^{78}$ In summer 1893, prompted by Foster, the Royal Society began considering the next step in earnest. It established a "Procedure Committee" to consider the feasibility of taking up some version of the recommendations that had been outlined by A Free Lance, Foster, and others, including exploring the option of centralizing the publishing activities of British scientific societies. ${ }^{79}$

But once this Committee's organizers began to vet their ideas with representatives of other societies, it became plain that the stakes might be interpreted in terms that went well beyond improving scientific workers' experience of the literature search. While enthusiasm for introducing rational organization into the literary marketplace of science was widespread, ${ }^{80}$ these proposals also prompted objections that they would "abolish competition" and "retard progress and endanger liberty" in the sciences. ${ }^{81}$ One sardonic reviewer's summary of A Free Lance's argument had made these stakes clear: British science, according to him, is wholesale robbery from beginning to end; this society steals the food of that; this journal poaches on the preserves of that; there is need of a well-organised detective force to stop pilfering and to recover the stolen property, and on the principle of setting a thief to catch a thief our "free lance" nominates the Royal Society to the part of the Howard Vincent of science. ${ }^{82}$

The language of thievery and recovery only made explicit that the organization of science question was not simply, or even primarily, about establishing a more efficient system to help scientists find out all that was new on this or that subject. It was just as much about the distribution of power to control who could speak the language of authoritative science. Some of these reformist aspirations may thus be read as a last-ditch effort by the major scientific societies - particularly the Royal Society - to wrest back from the broader marketplace of scientific print their traditional roles as arbiters of scientific opinion and value. (One advocate of reform - the chemist Henry Armstrong - would later label the position "scientific socialism". ${ }^{83}$ ) But the proprietors of commercial journals - whose publications now wielded so much power in the literary landscape of science - had little incentive to participate in any such scheme, while the 
smaller societies that published transactions would need to be convinced to surrender some of their autonomy to the greater cause of scientific coordination. Ultimately the Royal Society relented and reformulated some of the Procedure Committee's primary objectives on a less invasive, though geographically more ambitious, basis. In 1894, the Royal Society sent out a circular calling on scientific societies - not only in England, but across the globe - to participate in the founding of a massive international organization for the production of a running subject-classified card catalogue of world scientific production in print. This proposal would lead to the publication of the International Catalogue of Scientific Literature beginning in 1902.

Although the particular contours of the British perspectives I have just outlined were unique, the more general concern with the problem of the subject-based search and with scientific publication reform at this time went beyond Britain. Having documented some of the voices demanding reform, I turn now to surveying the diverse approaches and backgrounds of some of those who took it upon themselves to revolutionize search practices in the natural sciences. The greatest concentration of this activity was in Paris, where, during the 1890 s, endeavours to refashion the ways in which savants accessed knowledge in print were central to several competing visions for remodelling scientific communities.

\section{LES “HOMMES À FICHES”}

Les découpeurs ne sont pas des encyclopédistes. Charles-Mathieu Limousin (1895)

"Little by little it had begun to dawn upon me", recounted the American philologist Henry Alfred Todd upon returning from a bibliographical fact-finding mission in Paris in 1900, "that this curious difficulty of orienting myself in the burning subject of Bibliography was...due...to the emulation, not to say the rivalry, of the various bibliographical enterprises now represented in Paris" ${ }^{84}$ While French scientists' calls for bibliographical reform did not reach the rhetorical heights that they had in England, Paris instead witnessed an explosion of smaller grass-roots organizations dedicated to collecting, disseminating, and organizing print matter in the sciences. By 1900 it was home to a Bureau Bibliographique de Paris, an Institut de Bibliographie Scientifique, a Commission du Répertoire Bibliographique des Sciences Mathématiques, a Bureau Technique du Mois Scientifique et Industriel, a Bulletin des Sommaires des Travaux Scientifiques, a Société Bibliographique, a Répertoire Bibliographique Industriel, and a Bureau Français du Catalogue International de la Littérature Scientifique. Nearly all of these had been established within the previous decade and were dedicated to collecting, organizing, and making accessible in new ways information that had first appeared in scientific serials. ${ }^{85}$ Most were not directly connected with any learned society; they were private ventures, the vision of some entrepreneur who perceived some gap in the marketplace for scientific information. Many attempted to adapt for the sciences innovations that had been pioneered in the general press for the organization of print matter. Card catalogues, review journals, press clipping services, translation services, and circulating libraries were some of the basic elements out of which a new rational economy of scientific papers might be fashioned. The newspaper clipping service in particular, because it opened the possibility of customizing content to the needs of each individual user, represented an especially powerful model for would-be innovators in specialized scientific publishing.

In 1879, in the midst of a major boom in the mass press, ${ }^{86}$ a radically new form of print media service had made its debut in Paris. Alfred Chérié, an enterprising publisher and editor of countless serials, had the insight to offer artists the opportunity to receive clippings of notices of their work that had appeared in Parisian papers during the annual Salon de Paris exhibition. He named his service "La Correspondance artistique universelle". Although Chérié's original idea was essentially to help readers track references to their own names and works appearing in Parisian papers, other possible uses of such a service quickly became obvious. He renamed his business Argus de la presse, and it became the first of the press-clipping bureaus that flourished beginning in the last two decades of the nineteenth century. Users of the service subscribed on the basis of a set of subjects or names, and they subsequently received clippings of all articles on these topics that could be located by an army of professional 'lecteurs' who read through the 
daily papers on the lookout for whatever was relevant. The basic concept quickly spread to other major urban centres in Europe and the United States (Figure 2). ${ }^{87}$

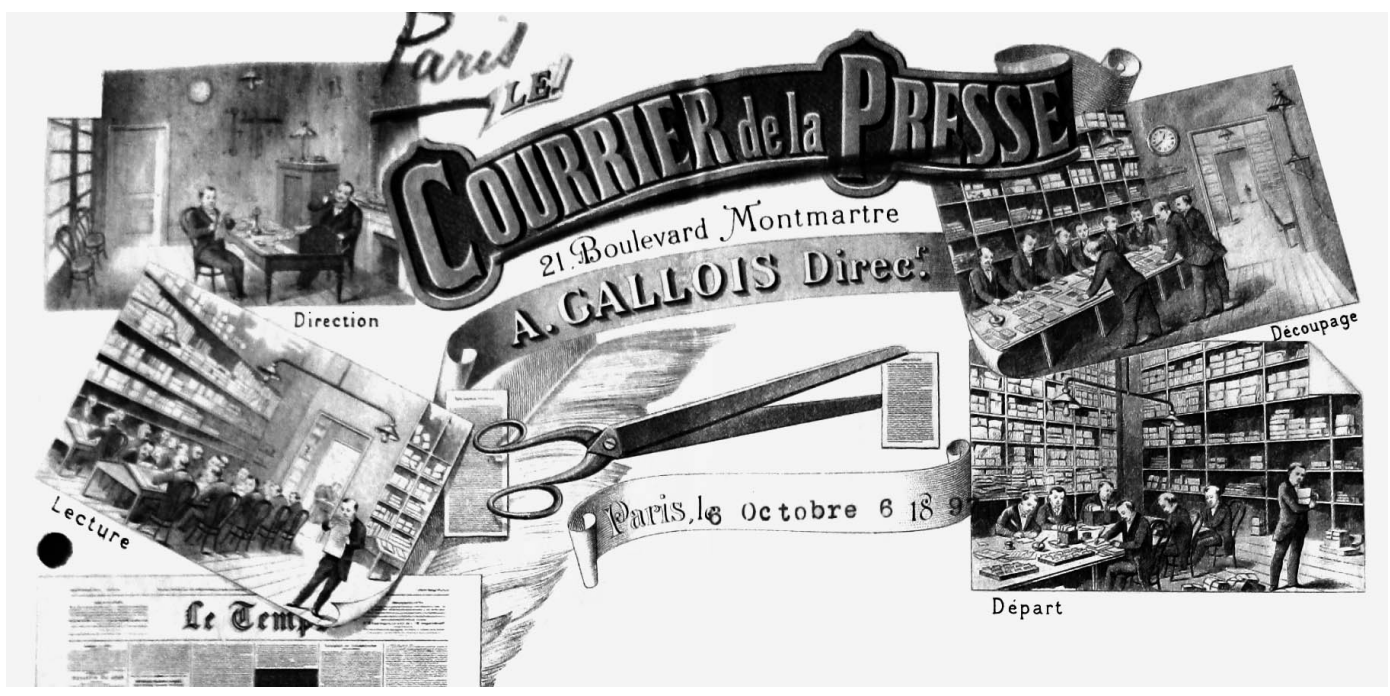

Fig. 2. Letterhead (1897) used by Courrier de la presse, a Parisian press clipping service, showing the various stages in the preparation of clippings: Direction, Lecteur, Découpage, and Départ. Detail from letterhead used in correspondence by the Courrier de la presse (6 October 1897) (APM Courrier, Collection Mundaneum, Mons, Belgium).

While such services were ultimately used by a wide range of organizations and individuals, they were not well suited for those looking for new information on topics in the natural sciences or other specialized endeavours. Despite the grand claims made by these services that they allowed their users to "see all", ${ }^{88}$ the world of serials was far too vast for any single organization to scan any substantive portion of it, and their main focus was usually on newspapers; none of these services seriously attempted to cover specialized periodicals. In the words of the publicist Charles Limousin, "Les découpeurs ne sont pas des encyclopédistes" ${ }^{89}$ Limousin reasoned that this gap in coverage was a perfect opportunity for others, more expert in the sciences, to adapt this innovation for scientific journals. He invented the term

éphémérographie to designate bibliographical activity that took as its object periodical literature. A number of enterprising journalist-scientists laid plans in Paris to try their hand at this new field of scientific journalism. The three that I will focus on here - Marcel Baudouin, Limousin, and Herbert Haviland Field each founded enterprises that adapted and combined some of the new innovations developed by the general press for what they perceived to be the special needs of the 'travailleur scientifique'.

Marcel Baudouin's Institut de Bibliographie Scientifique ${ }^{90}$ (f. 1894) was, among all of these services, perhaps the most ambitious in its design. He aimed at building up a "vast organization...for enhancing, in a way never before seen, the bibliographical research work of savants". ${ }^{91}$ At the centre of his vision was the index card - 'la fiche' (Figure 3); it would form the basic building block of a massive repository of information about scientific papers to be constructed continuously over time.

Baudouin had been deeply impressed by the Index medicus, a current bibliography for the medical sciences founded in 1879 by the American doctor and bibliographer John Shaw Billings. ${ }^{92}$ Billings's serialized bibliography had quickly established itself as the model for a periodical index of specialist literature. By the 1890s, however, it was verging on financial ruin. Baudouin's eureka moment occurred when he realized he could not only pick up where Billings was forced to leave off, but he could do it better, by exchanging the outmoded book format of the Index medicus for what amounted to a combination of a vast card catalogue and clipping service. ${ }^{93}$ Instead of receiving the yearly volumes in their entirety, subscribers would select the particular key words or sub-disciplines that interested them, and the Institut agreed to dispatch copies of all new fiches bibliographiques relevant to those subjects on a running basis. This system would save subscribers the cost and trouble of receiving references to every single indexed 
FICHE POLR VOLUME.

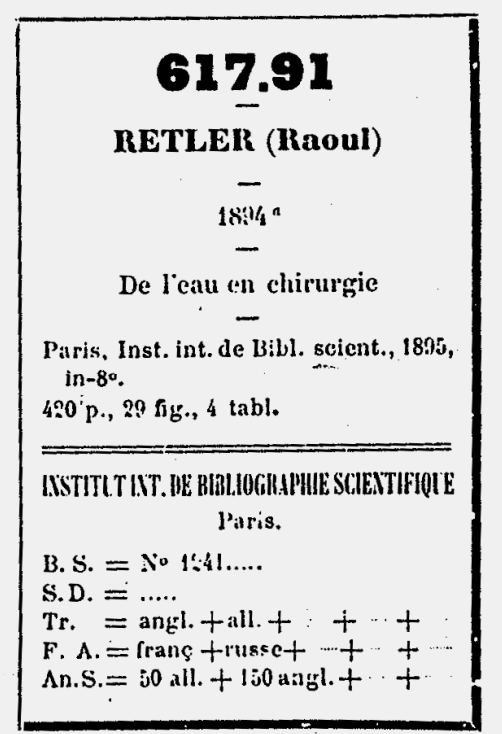

Schéma de ñche pour livre français (Grandeur nature).
FICHE POUR AITTCLE DE JOURNAL.

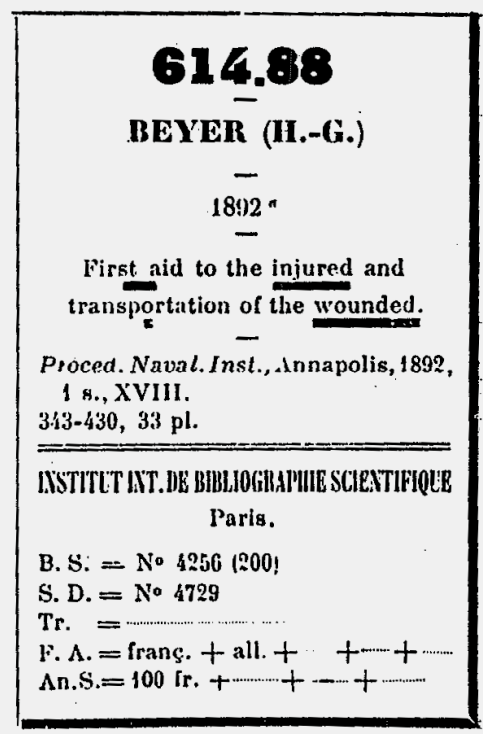

Fiche pour article de journal américain.

Fig. 3. Model of Baudouin's fiches. The information at the bottom indicates what forms of information the Institut possesses for the work in question (S. D. = Service des Découpures, Tr. = Traductions, F. A. = Fiches Analytiques, An. S. = Analyses Scientifiques). "Le problème bibliographique", Revue scientifique, iv (1895), 708-15, p. 713.

paper in medicine, and it would allow - at least in principle - a quicker turnaround time for getting relevant information to subscribers. Baudouin boasted that he had "invented a process that could instantaneously...put at the disposition of doctors the most complete, most perfect bibliographical documents available anywhere". ${ }^{94}$ One might have pointed out to Baudouin that such a service alone left open the possibility that the publications indexed might not themselves be readily available to many of his scattered subscribers: bare references only went so far. Not a problem: Baudouin also offered fiches analytiques: these were cards containing abstracts of books and articles that his staff would produce on an on-demand basis. (The Institut claimed that, given enough lead-time, it could produce these abstract cards in any language their subscribers desired.)

This was not all; the roster of services on offer was always expanding. (Figure 4 contains a listing of them with prices for 1896.) There was also a circulating library; inspired by Mudie's Select Library of London, ${ }^{95}$ Baudouin offered to lend out any book in the Institut's collection by post. ${ }^{96}$ Baudouin had provincial subscribers especially in mind, but even in Paris, lending libraries for specialized publications were virtually unheard of, and the larger libraries were notorious among savants for being difficult to use. ${ }^{97}$ He also advertised a translation service, a clipping and copying service, a service de bibliothéconomie (a service that would assemble private libraries for savants or doctors by furnishing them with an appropriate set of starter publications as well as library furniture, and would also renovate existing libraries by reclassifying their contents), and the services of a commercial publisher. On the model of news agencies such as the Agence Havas, Baudouin also hoped to become a central agency for distributing scientific news to journals themselves. ${ }^{98}$ 


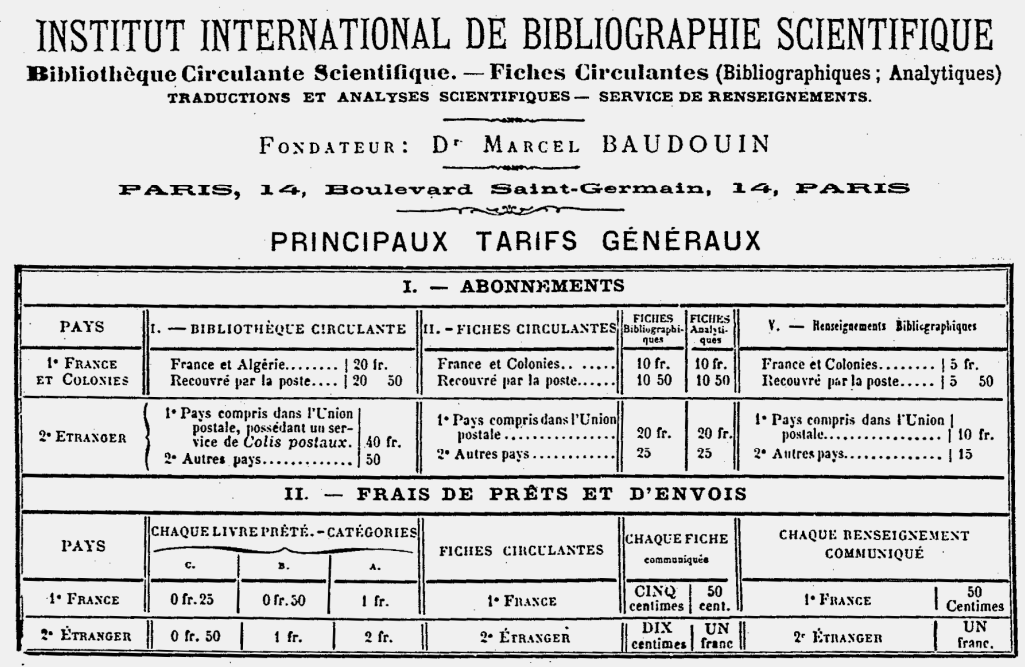

Fig. 4. Institut International de Bibliographie Scientifique: Price list, 1896

Charles Limousin's scheme was both broader and less comprehensive than Baudouin's. His Bulletin des sommaires des journaux scientifiques, littéraires, financiers (f. 1888-) picked up where generalist indexing journals left off and provided subscribers a bibliographical guide to the contents of more specialized serial publications (Figure 5). Unlike Baudouin, he did not start from one specialty with a plan to expand out later on but indexed whichever periodicals he could reliably get his hands on. Although he barely ever reached the point where he could offer users personalized content delivery, his enterprise was inspired directly by the press clipping bureaus; he collaborated directly with the directors of Argus de la presse, with the hope that they might feed clients back and forth. Icons and narratives of découpage and classification abounded; there was a regular column titled "Coups de ciseaux". By 1896 the Bulletin had been formatted so that users could cut up its pages and paste them onto individual reference cards, and he offered his users instructions on how to transform his Bulletin into an indexed card catalogue. (To this end, he published the journal in a single-sided version.) Limousin's grand hope was that he would eventually convince the French Ministry of Public Instruction to take up his project on a grander scale, and to found a bureau to regularly clip and index all current French serials so as to make expert knowledge in print accessible to all interested citizens. ${ }^{99}$

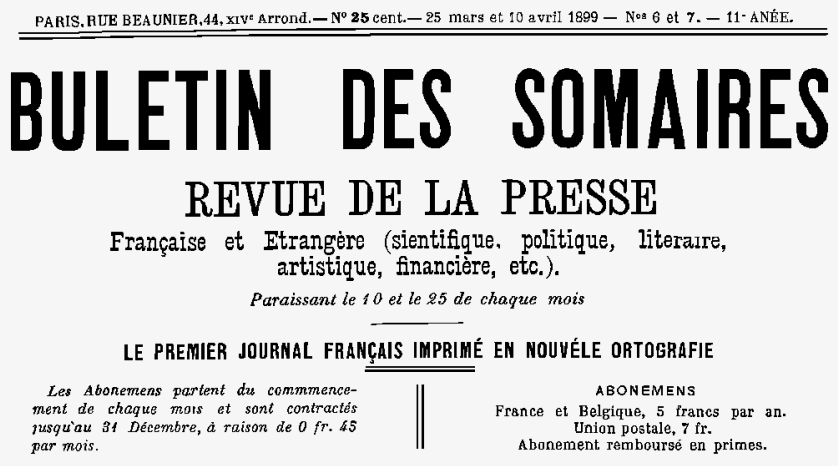

Fig. 5. The Bulletin des sommaires title page in 1899. (Note that Limousin was an advocate of reformed orthography.) 
Both Limousin and Baudouin were deeply motivated by what Baudouin called "la décentralisation scientifique". Baudouin had grown up in the coastal village of Saint-Gilles-Croix-de-Vie and had always remained fiercely loyal to his provincial roots. (Later in life he returned to his native village to document its archaeological riches.) But he approached the technical aspects of his scheme through his combined experience as a physician ${ }^{100}$ and as a writer for the medical press; on arriving in Paris in 1883 to complete his medical education, he had immersed himself in editorial work for commercial medical journals, ${ }^{101}$ and by 1892 he was the secretary of the Association de la Presse Médicale Française. Limousin, on the other hand, came at the problem directly from his experience of the rapidly changing world of the wider periodical press. Limousin was a typographer and disciple of Pierre-Joseph Proudhon, the great anti-state socialist; in 1865 he became a secretary of the Paris Branch of the International Workers Association (the First International) when his father Antoine, withdrew due to ill-health. He became an important publicist for socialist causes, editing several publications. In 1880 he founded the influential monthly, Revue du mouvement social; over time, however, he gradually shifted the political focus of the Revue toward informing his readers more widely about developments in a range of contemporary issues in the sciences and the arts. In 1887 he wound down the Revue and replaced it with the Bulletin to accomplish this in a more systematic way. Adapting his Proudhonist brand of decentralized socialism, Limousin aimed to bring the democratizing possibilities of the mass press to the sciences, not by engaging in vulgarisation, but by making specialized research work in the sciences practically accessible to fellow workers: "In the many countrysides of Brittany or Burgundy, the Alps or the Pyrenees, as well as lands in between, there are workers, thinkers, artists desiring to stay current on the work of their colleagues, and to communicate to their colleagues the results of their own researches and meditations". ${ }^{102}$ What Limousin was aiming for was not so much the breaking down of the boundary between expert and lay readers, but instead levelling the playing field of information among fellow travailleurs by democratizing access to their particular specialized literature.

The impetus for Herbert Haviland Field's Concilium Bibliographicum - a service for the distribution of subject-based cards for zoological publications - originated more squarely at the laboratory bench, but it was also motivated in part by the problem of decentralization. In 1890, Field was an American graduate student studying for his doctorate on the embryology of amphibians in the laboratory of E. L. Mark at Harvard University. It was in this lab, far from the European centres of power in biology, that he first developed a fascination with the circulation of scientific information. A culture of keeping classified index cards had spread rapidly throughout America's libraries during the mid-nineteenth century, and it was particularly strong at Harvard. ${ }^{103}$ Mark himself had seen his primary pedagogical obligation to his students as training them in precisely two skills: one was modern methods of microscopic anatomy, and the other was modern methods of bibliography. Among other things, "students were encouraged", he recalled, "to form the habit of making out their bibliographic references on separate cards of standard size, and advised always to carry about with them blank cards for this purpose..." ${ }^{104}$ Field, a polyglot known for a prodigious memory, was thus especially well placed to grasp the potential further uses of this information technology. Upon completion of his Ph.D. he set off for Europe to make the customary rounds in eminent European laboratories, and it was at this time that he began to plot his vision for a bibliographical empire. $^{105}$

In 1894 Field settled in Paris and joined Alphonse Milne-Edwards's laboratory at the Muséum d'Histoire Naturelle. He began taking part in the newly-burgeoning life of the Société Zoologique. Under the leadership of Raphaël Blanchard, the Société ${ }^{106}$ had made a name for itself by hosting the first International Zoology Congress (1889) and by pushing zoologists to forge an international entente for zoological nomenclature. ${ }^{107}$ Blanchard's unrelenting work to establish rules for standardized zoological names forced him to confront questions that ranged from the long-standing epistemological problem of just what zoological names and species were ${ }^{108}$ to the concrete problem that such rules required material vehicles of transmission and registration in order to be anything more than idealistic fantasies. ${ }^{109}$ The members of the Société were thus well disposed to grasp the important of Field's bibliographical vision when he laid it before them early in 1894: he predicted that his enterprise would help provide a material substrate for bringing about nomenclatural order. ${ }^{110}$ Blanchard himself soon joined a new commission of 
French scientists studying the problem of scientific bibliography. ${ }^{111}$ The Société's central role in fostering international contacts among zoological organizations was a boon as Field now began to negotiate with many European and American learned societies, governments, and bibliographers to generate consensus on the need for, and rightness, of his plan. The lobbying of Blanchard and E.-L. Bouvier helped give the matter of bibliography a prominent place at the 1895 International Zoological Congress in Leyden. ${ }^{112}$ As is well known, this conference saw the establishment of the first International Commission on Zoological Nomenclature (and the Code that remains the basis for current zoological naming conventions), but, thanks to the efforts of Blanchard, it also saw the founding of an International Bibliographical Commission to oversee a central bureau of zoological bibliography to be run by Field. ${ }^{113}$

The Concilium ultimately set up operations in Zürich, as the Swiss government had offered to underwrite the venture. Field had already gathered the support of a network of powerful scientific supporters. Besides the Société Zoologique, he had established close relations with the Zoological Station in Naples, as well as with Julius Victor Carus, founding editor of both the Zoologischer Anzeiger and the Zoologischer Jahresbericht (and, according to Field, the "Nestor" of scientific bibliography). Field employed both clerks and trained zoologists, who recorded and classified the continuous stream of publications flowing into the Zurich Bureau, sent in by authors, editors, and scientific societies (Figure 6). By 1906, the Concilium was going strong; it had distributed over 2 million cards to users, and had indexed 68,000 zoological articles. ${ }^{114}$ It had amalgamated with the Zoologischer Anzeiger, and, while its finances always remained precarious, it achieved significant recognition from zoologists in a number of European countries.

67.86 Anstralomantis. Rohn 1961.

n. g. pro Harpase Bmavilin non Panemaox. Canad. Entom. Vol. 88 p. 271.

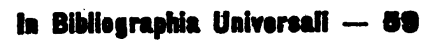

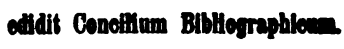

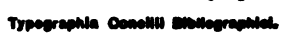

Fig. 6. A sample card published by the Concilium Bibliographicum. Card sample published in Annotationes Concilii bibliographici, i (1905), 18. More samples can be found in G. M. Doolittle, "A history of the Concilium Bibliographicum, Zurich”, Master's thesis, Columbia Library School, 1929).

Each of these three enterprises pursued different strategies for attracting content, users, and funding. While Field's most important sources of support were institutional subscribers and underwriters (both public and private), Baudouin and Limousin chose to focus more on individuals. Baudouin was constantly on the lookout for new paying subscribers - his fee structure was as baroque as the vast array of services on offer - whereas Limousin focused on winning over the editors of periodicals themselves.

Limousin, in fact, hoped to supply his users with his publications free of charge by convincing publishers that his service amounted to a sorely needed organ of publicite for their own wares; ${ }^{115}$ he ventured that they would eventually be willing to pay to have the contents of their publications indexed and advertised by his team.

Limousin's strategy was revealing in both its ambition and its ultimate failure. Despite his zeal for éphémérographie, he did not develop a very successful strategy for dealing with the problems of specialization that so exercised his contemporaries. By focusing on specialized fields but not restricting himself to any particular specialization, he was hampered from accumulating a critical mass of periodical content in any one branch of knowledge. Nor did he anticipate, considering his dependence on the active good will of journal editors, the potential effects of a service such as his on the periodicals that he hoped to 
index. Press-clipping services themselves had not been a serious source of competition for newspapers and magazines as long as editors could count on subscribers who were interested in reading through their publications more or less as a whole. But the same was not necessarily the case in the more specialized scientific press, where reading habits and scales of distribution might potentially be radically different witness some editors' trepidation at supplying authors with even a dozen or so off-prints - and where an efficient information clearing-house might be enough to convince readers interested in a narrow range of subjects entirely to forego subscribing to the serials themselves. This difficulty touched Baudouin's and Field's enterprises less directly - they were primarily beholden to their paying subscribers - but it was not irrelevant. While none of these entrepreneurs intended their services to compete directly with scientific periodicals themselves, had any one of them been completely successful, ${ }^{116}$ they could potentially have accomplished many of the same centralizing aims that had been articulated by the most radical reformist voices in Britain.

What Baudouin, Limousin, and Field - the "hommes à fiches"117 - also shared with British reformers was that their schemes ultimately led them to the problem of classification: each finally opted to establish a systematic basis for the indexing of the subjects that they treated. All three of them, in fact, eventually affiliated themselves with the Institut International de Bibliographie that had been founded in Brussels in 1895, and they all contributed to its program to expand the Dewey Decimal System (which had been imported from America for the purpose) into a detailed universal classification of knowledge - one that its designers hoped would form the basis of an international and interdisciplinary language for savants. ${ }^{118}$ In this way their enterprises brought them into direct opposition with the massive cooperative classification project that the Royal Society launched at the same moment in connection with its plan to found an International Catalogue of Scientific Literature. ${ }^{119}$

\section{CONCLUSION}

In the final years of the century, the two milieus that I have described in this essay came into dialogue in the conflict over the question of bibliographical classification. But their differing perspectives on just what sorts of solutions were required to bring organization and efficiency to scientific publishing were already well established. To a certain extent, these differences may be ascribed to the particular social topographies of science that had developed in France and Britain over the course of the nineteenth century. The appeals for centralization and order that characterized the British debate may be viewed in the light of the vast array of specialized and local scientific societies that, along with commercial publications, could make British scientific communities seem to be dangerously fragmented and dispersed. That the deeprooted British experience of attempting to govern a vast empire by information was crucial here is indicated by the motto that appeared on the title page of A Free Lance's pamphlet on the organization of science: "Divide et impera". In contrast, the grassroots approach to 'decentralisation scientifique' of small information entrepreneurs in France fit naturally with efforts during the Third Republic to bring greater parity to the centralized power structures of French science (and thereby to challenge the influence of the Ministry of Public Instruction and the Académie des Sciences). ${ }^{120}$ Baudouin, Limousin, and Field each exemplify a pattern whereby many of those who have been most enthusiastic about producing new formal search tools for scientific information have been figures outside of the traditional centres of scientific power on the lookout for strategies to redress this imbalance.

Despite these important differences in emphasis, the more general turn to the problem of classifying the sciences suggests that both milieus were responding to a similar, if deeper, underlying challenge. I have argued that this challenge was the ascendancy of the scientific periodical. The key point was not the increasing volume of papers coming into print, but rather that the specialized periodical press was becoming a principal locus for demarcating scientific authority and value. But while the scientific paper during the twentieth century would indeed become the primary unit of measurement for the bureaucratic assessment of scientific achievement (both collective and individual), the story of its coming to play this role is not that of its at last becoming the source of immutable mobility that it was always destined to be. Rather, this crucial development only took place following the failure of the authority of the 
collectives that had traditionally adjudicated the boundaries of scientific authority. In the aftermath of this failure - in which the press was no saviour of social order, but rather its principal assailant - men of science were compelled, however awkwardly, to invest the scientific paper with the mechanisms - such as peerreview, arbitration of priority, and evaluation of professional qualifications - for safeguarding scientific value that had once been the putative territory of the societies and academies. At the same time, the virtuous man of science was subtly being redefined in terms of the supposedly impersonal and objective criteria of the printed page: being a member in good standing with this community meant keeping up with the literature of the field, publishing in appropriate - as a rule, periodical - venues, and not publishing so indiscriminately as to sully the pure stream of science.

Only then did the profusion of specialized periodicals appear as disorder and confusion, and only then did this represent a threat to the moral authority of the scientific community itself. Attempts at rationalizing the subject-based literature search that exercised men of science in the late nineteenth century were a crucial aspect of this larger program to tame and to harness the periodical literature in the interests of establishing new community standards. This context also helps to explain the broad turn to standardized subject classification at the end of the century. Like press clipping bureaus, standardized classification systems were an innovation that had its roots in the mass press (in this case, the organization of public libraries). But now this practical solution to the arrangement of books on shelves became entangled with the long-standing - and just-then thriving - philosophical problem of the classification of the sciences. The nineteenth-century version of this genre had its roots in classifications proposed by Jeremy Bentham (1816), Auguste Comte (1830), and A.-M. Ampère (1834), and - although often linked with projects for curricular reform - it had remained largely a matter of speculative metaphysics. But with the emergence of the problem of bibliographical classification at the end of the century, the philosophical problem became absorbed by the more empirical and practical questions of organization that now captivated scientists. The goal was now equally material and metaphysical; as Baudouin put it, through a judicious classification the scientific community "would possess not simply a repertoire of cards, but a true catalogue of original ideas". ${ }^{121}$ As men of science increasingly looked to periodical publications not only as vessels to hold "broken pieces of fact", but as the primary repositories of genuine knowledge, they embarked on collective experiments to forge new synthesizing genres that would bring the increasingly serialized character of scientific representation into harmony with their own varied commitments to the unity of knowledge.

\section{ACKNOWLEDGEMENTS}

I am very grateful to Nick Hopwood, Simon Schaffer, and Jim Secord for the opportunity to participate in the Seriality project, and especially to Jim Secord for his suggestions and encouragements. The argument behind Seriality has proven to be more crucial to my work than I had at first imagined, but it took Jim's subtle, yet persistent, coaxing to help me fully to see it. I owe many thanks also to the participants of the final Seriality workshop at Cambridge in April 2009, as well as to Mario Biagioli, Janet Browne, Peter Galison, Lisa Gitelman, Chris Phillips, Steven Shapin, Hanna Rose Shell, Megan Shields Formato, Elizabeth Yale, Nasser Zakariya, and the Harvard Book History Writers' Group for their very helpful readings of earlier drafts of this essay.

\footnotetext{
${ }^{1}$ Hooker to Darwin, [before 7 Mar. 1855], in F. Burkhardt et al. (eds), The correspondence of Charles Darwin (Cambridge, 1985-; hereafter CCD), v, 277-8.

${ }^{2}$ Arthur Henfrey (ed.), Botanical and physiological memoirs (London, 1853), 312-13. 'Books to be Read' notebook (1852-1860), f. 177, in CCD, iv, 482.

${ }^{3}$ L'ancien régime et la révolution (1856), Livre 3, chap. IV, "Que le règne de Louis XVI a été l'époque la plus prospère de l'ancienne monarchie, et comment cette prospérité même hâta la Révolution".

${ }^{4}$ Darwin wonders about the form of the document in his letter to Arthur Henfrey on 17 Mar. [1855], in CCD, v, 286. Darwin's original reference in his "Books to be Read" notebook (ref. 2) seems only to have consisted of the information in the original citation, "Godron, De l'Espèce et des Races." Other details were added later on when Darwin learned them. An image of the relevant notebook page may be viewed at The complete work of Charles
} 
Darwin online, CUL-DAR128, f. 177, http://darwin-online.org.uk/content/frameset?itemID=CUL-DAR128.-

\&viewtype=image \&pageseq $=7$.

${ }^{5}$ See Darwin to Henfrey, 17 Mar [1855] (ref. 4). For more on Darwin's reading habits, see Susan Sheets-Pyenson,

"Darwin's data: His reading of natural history journals, 1837-1842", Journal of the history of biology, xiv (1981), $231-48$.

6 "I am very sorry that you have had such extra bother about Godron ... . it is too bad in me, though the unintentional cause of all this trouble", Darwin to Hooker on 7 Mar [1855], in CCD, v, 279.

${ }^{7}$ Darwin to Henfrey on 17 and 31 March $1855 C C D, \mathrm{v}, 286,295-6$. Braun's original, Betrachtungen über die

Erscheinung der Verjüngung in der Natur (Leipzig, 1851) contains no more information.

${ }^{8}$ Darwin to Lyell, 18 May 1860, CCD, viii, 218; Darwin to Hooker, 15 [June] 1855, CCD, v, 354. Darwin was reading Florula juvenalis, ou, énumération des plantes étrangères qui croissent naturellement au Port Juvénal, près de Montpellier, précédée de considérations sur les migrations des végétaux, 2nd edn (Nancy, 1854).

${ }^{9}$ Darwin to Hooker, 10 Aug, $C C D$, v, 403-4. Godron's citation of his own work was actually to two distinct papers in consecutive volumes of the Mémoires de la Société des Sciences, Lettres et Arts de Nancy (1848, pp. 182-288 and 1849, pp. 111-150). Darwin did mark the paper as read in his "Books to be Read" notebook, but it is likely this was done only after reading the later book (see below).

${ }^{10}$ Darwin provides running commentary on his reading of Godron in letters to Lyell, 18 May 1860; Hooker, 22 [May] 1860; Lyell, 6 June 1860, CCD, viii, 218, 226, 243-4.

${ }^{11}$ Darwin to Henfrey, 31 Mar. [1855], CCD, v, 395-6. H. E. Strickland (ed.), Bibliographia zoologiae et geologiae: A general catalogue of all books, tracts, and memoirs on zoology and geology (London, 1848-54).

${ }^{12}$ Comptes rendus hebdomadaires, xxvi (1848), 487.

${ }^{13}$ In the case of Braun, this is established by the page numbers he cites, and in the case of the Comptes rendus, by the date his pamphlet is listed as received: 1 May 1848. (The volume of Mémoires for 1847 could not have been published earlier than July 1848 , for it contains a members list that is current as of that month.) Besides pagination there are other subtle differences: although the typesetting is nearly identical, the position of each page in its corresponding signature is offset by five pages, and Godron has made one set of corrections: all of his page references to the Oeuvres of Buffon (which he appears initially to have copied from references in P. Flourens, Analyse raisonnée des travaux de Georges Cuvier (Paris, 1841)), have been changed to page references to the first edition of the Histoire naturelle. (New errors were simultaneously introduced, and were finally corrected only in the 1859 monograph.)

${ }^{14}$ The monopoly that the peer-reviewed journal exercised as the rightful channel by which to circulate and to stake scientific claims during the twentieth century is now giving way to a new mixed economy of genres that include preprint archives, working papers, and patent documents.

${ }^{15}$ On what is arguably the first instance of the new genre, François Rozier's Observations sur la physique, sur l'histoire naturelle et sur les arts (f. 1771), see J. E. McClellan, "The scientific press in transition. Rozier's journal and the scientific societies in the 1770s", Annals of science, xxxvi (1979), 425-449.

${ }^{16}$ By the late eighteenth century this was even true of the Royal Society's Philosophical transactions, which, once the Royal Society took responsibility for it in 1852 , had gradually shifted from being a monthly or quarterly philosophical newsletter to resembling the more lavish and less frequently-published Mémoires of the French Académie des Sciences.

${ }^{17}$ This difficulty is discussed in some detail in the Rapport sur la réforme de la bibliographie scientifique (Paris, 1895) put together by a committee of the Association Française pour l'Avancement des Sciences.

18 "Autobiography of a physiologist" [on Karl Ernst von Baer], The quarterly review, cxxii (1867), 335-47, p. 343.

${ }^{19}$ On the continuing importance of conversation in scientific work and for establishing priority in mid-century Britain, see James A. Secord, "How scientific conversation became shop talk", in A. Fyfe and B. Lightman (eds), Science in the marketplace: Nineteenth-century sites and experiences (Chicago, 2007), 23-59; and "Science, technology and mathematics", in Cambridge history of the book in Britain, v (Cambridge, 2009), 443-74, p. 444.

20 "The new planet", The civil engineer and architect's journal, ix (1846), 331-2. See George Airy, "Account of some circumstances historically connected with the discovery of the planet exterior to Uranus", Memoirs of the Royal Astronomical Society, xvi (1847), 385-414, and Robert W. Smith, "The cambridge network in action: The discovery of Neptune", Isis, lxxx (1989), 395-422.

${ }^{21}$ Arago, "Examen des remarques critiques et des questions de priorité que la découverte de Le Verrier a soulevées", Comptes rendus hebdomadaires, xxiii (1846), 741-55, p. 751. (All translations from the French are my own.) For the fiercest denial of the priority of print in the context of the Neptune affair see David Brewster, "Researches respecting the new planet Neptune", North British review, vii (1847), 207-46. I am here extending to the nineteenth century arguments that Adrian Johns has made about the ambiguous role of print for early modern experimental collectives. 
Johns himself speculates how such an argument might proceed for the nineteenth century in the concluding chapter of The nature of the book (Chicago, 2000).

22 "A conspectus of science", Quarterly review, cxcvii (1903), 139-60, pp. 147-8.

${ }^{23}$ Heroic narratives of the scientific journal have often looked to the founding of the Philosophical transactions as if this event definitively established an ideal solution to making things public in the modern sciences. See for instance Mary Boas Hall, Henry Oldenburg: Shaping the Royal Society (Oxford, 2002). The same heroic account of the scientific journal has been used in guides to ethical research and publishing in the sciences. See On being a scientist: Responsible conduct in research (Washington, DC, 1995) published by the Committee on Science, Engineering, and Public Policy in the United States, pp. 9-10.

24 "The bibliography of periodical literature", The library, viii (1896), 49-64, p. 49.

${ }^{25}$ A detailed conception of 'genres of synthesis' has recently been developed by Nasser Zakariya in the context of twentieth-century physicist George Gamow's efforts to imagine and develop possible forms for the unification of science. In Zakariya's usage, the emphasis is on the formalist dimensions of 'genre' (his principal categories are the historical, the exploratory, the scaled, and the foundationalist), whereas my focus is on the material formats scientists envisaged for producing a 'conspectus of science'. We share, however, a deep commitment to tracing links between conceptual forms for imagining the unity of science and the representational genres with which these have usually been coproduced. (See chap. 2 of Nasser Zakariya, "Towards a final story: Time, myth, and the origins of the universe", Ph.D. dissertation, Harvard University, 2010.)

26 "Decentralisation in science", Nature, xxviii (1883), 386.

${ }^{27}$ For various early modern iterations of this trope see for instance James Bono, The word of God and the languages of man (Madison, 1995).

${ }^{28}$ J. C. Maxwell, "Essays at Cambridge-1853 to 1856", in The life of James Clerk Maxwell (London, 1882), 354; Hermann von Helmholtz, "Über das Verhältniss der Naturwissenschaften zur Gesammtheit der Wissenschaft" [1862], in Populäre wissenschaftliche Vorträge (Braunschweig, 1865), 1-30, p. 12; Lord Rayleigh, "Presidential address", in Report of the fifty-fourth meeting of the British Association [in 1884] (London, 1885), 3-23, p. 20; Henri Poincaré, "Les relations entre la physique expérimentale et la physique mathématique", in Rapports du Congrès International de Physique (Paris, 1900), 1-29, p. 4.

${ }^{29}$ The best source on the history of the Institut is W. Boyd Rayward, The universe of information (Moscow, 1975).

${ }^{30}$ On the organisation of science (London, 1892). A Free Lance was a pseudonym for Frank H. Perry Coste (later Perrycoste) (1864-1928). Trained as a botanist (B.Sc. 1891, joined the Linnean Society the same year), this brief but eventful foray into science policy helped inspire him to reinvent himself as a social philosopher in the Spencerian mode. His next major work, Towards utopia (being speculations in social evolution) (London, 1894), extended his advocacy of rational organization in science to the human race in general.

${ }^{31}$ E.g., Michael Foster, "On the organisation of science", Nature, xlix (1894), 563-4, p. 563; T. D. A. Cockerell, "A suggestion for the indexing of zoological literature", Nature, xlvi (1892), 442; and A Free Lance, op. cit. (ref. 30), 4.

${ }^{32}$ E.g. Review of reviews (British), x (1894), 194; and Nature, i (1894), 539.

${ }^{33}$ E.g. Foster, op. cit. (ref. 31), 564; and Henry Armstrong, "Scientific bibliography", Nature, liv (1896), 617-18, p. 618.

${ }^{34}$ F. G. Donnan, "The organisation of scientific literature", Nature, xlviii (1893), 436.

${ }^{35}$ See the essays by Ann Blair, B. W. Ogilvie, and R. R. Yeo in D. Rosenberg (ed.), Early modern information overload, special issue of the Journal of the history of ideas, lxiv, no. 1 (2003). In his introductory essay, Rosenberg suggests the possibility that "perceptions of information overload have less to do with the quantity of information in production or circulation at any time than with the qualities by which knowledge is represented" (p. 9). This is my view precisely.

${ }^{36}$ For the figure of 'indigestion' see Barnabe Rich, A nevv description of Ireland (London, 1610) ("Epistle to the Reader", n.p.); for an extended used of the 'flood' metaphor see H. Basnage de Beauval, Histoire des ouvrages des savans, July 1688, 339 ("une espece de deluge, \& un debordement de Livres qui menace d'inonder la Republique des Lettres").

${ }^{37}$ M. Foster, "The organisation of science", in Atti dell'XI Congresso Medico Internazionale Roma (Rome, 1895), 246-56, p. 254.

${ }^{38}$ E.g. T. J. Parker, "Suggestions for securing greater uniformity of nomenclature in biology", Nature, xlv (1891), 689; Cockerell, op. cit. (ref. 31); T. R. R. Stebbing, "On random publishing and rules of priority", Natural science v (1894), 337-44; F. A. Bather, "Zoological bibliography and publication", in Report of the sixty-seventh meeting of the British Association [in 1897] (London, 1898), 359-62. 
${ }^{39}$ On the moral obligation to search the literature, see for instance, D. Sharp, The object and method of zoological nomenclature (London, 1873), 17; and Foster, op. cit. (ref. 37).

${ }^{40}$ J. S. Billings, "Our medical literature", in Transactions in the seventh session of the International Medical Congress (London, 1881), 54-71, p. 55.

${ }^{41}$ A Free Lance, op. cit. (ref. 30), 28.

${ }^{42}$ Foster, op. cit. (ref. 31), 563.

${ }^{43}$ That there was a social geography to search practices, and that it was precisely students and more marginal figures who tended to be most exercised by the problem of formal access to the literature, was a point often remarked upon. See "Order or chaos?" Nature, xlviii (1893), 241; and "Zoological nomenclature", Natural science, viii (1896), 218.

${ }^{44}$ On the history of bibliographical listings, see Luigi Balsamo, Bibliography: History of a tradition (Berkeley, 1990), 143-76. Subject-specific bibliographies for monographs were widespread during the eighteenth century.

${ }^{45}$ E.g., Oliver Lodge, "The publication of physical papers", Nature, xlviii (1893), 292-3.

${ }^{46}$ See E. A. Minchin, "A plea for an international zoological record”, Nature, xlvi (1892), 367-8; and F. A. Bather et al., "An international zoological record", Nature, xlvi (1892), 416-17.

${ }^{47}$ Stebbing, op. cit. (ref. 38), 337, 338; Cockerell, op. cit. (ref. 31), 442.

${ }^{48}$ See A. Cayley, R. Grant, and G. G. Stokes, in Report of the twenty-sixth meeting of the British Association [in 1856] (London, 1857), 463-4. Plans for a subject index were repeatedly postponed and made real progress only once its successor, the International Catalogue project, forced a solution to the divisive question of classification. The final volume of the original Catalogue, completing the century, eventually appeared in 1925.

${ }^{49}$ See Secord, op. cit. (ref. 19), 444.

${ }^{50}$ The Catalogue listed Godron's paper, along with its serial source, in vol. ii, published in 1868 .

${ }^{51}$ For commentary from scientists on the pros and cons of using the Catalogue of scientific papers, see the numerous responses the Royal Society received to its proposal for a new International Catalogue (Archives of the Royal Society, MS 531).

52 "Two workers at a given subject living in different parts of the world invent each a terminology of his own. Each system is adopted by the inventor's own friends or countrymen" (Parker, op. cit. (ref. 38), 68).

${ }^{53}$ See Harriet Ritvo, "Zoological nomenclature and the empire of Victorian science", in B. Lightman (ed.) Victorian science in context (Chicago, 1997), 334-53, p. 338.

${ }^{54}$ H. E. Strickland et al., "Report of a Committee appointed 'to consider the rules by which the Nomenclature of Zoology may be established on a uniform and permanent basis"', in Report of the twelfth meeting of the British Association [in 1842] (London, 1843), 105-21, p. 114.

${ }^{55}$ Daydon Jackson (ed.), Index Kewensis (1893-). Hooker's description of Darwin's role is quoted in Kew bulletin of miscellaneous information, vii (1893), 343.

${ }^{56}$ Although indexes and catalogues for academic research would continue to proliferate throughout the twentieth century across many disciplines, the question to what extent and how they have actually been used by researchers has received little historical attention. A start, for the case of twentieth-century social sciences, has recently been made in an excellent series of papers by Andrew Abbott. See "The traditional future: A computational theory of library research", College and research libraries, lxix (2008), 524-45.

${ }^{57}$ See "Suggestions by Professor Armstrong", Procedure Committee Minutes (Archives of the Royal Society, CMB 43).

58 "Physics at the British Association", Nature, xlviii (1893), 525-9, p. 529.

${ }^{59}$ The problem of language barriers was often remarked upon. See for instance Lodge, op. cit. (ref. 45), 293.

${ }^{60}$ James Swinburne, "The publication of physical papers", Nature, xlviii (1893), 197-8, p. 197. Swinburne would be a central figure in the founding of Science abstracts in 1898, established jointly by the Physical Society and the Institution of Electrical Engineer; its direct descendant, Inspec (1967-), remains one of the chief abstracting services for physics and engineering papers.

${ }^{61}$ Lodge, op. cit. (ref. 45), 292-3.

${ }^{62}$ S. P. Thompson, "The diffusion of scientific memoirs", Nature, xxix (1883), 171.

${ }^{63}$ J. Y. Buchanan, "Publication of scientific papers", Nature, xlviii (1893), 340-1.

${ }^{64}$ See for instance A. P. Trotter, "The publication of physical papers", Nature, xlviii (1893), 412-13; and A Free Lance, op. cit. (ref. 30), 8 .

65 "Order or chaos?" (ref. 43), 241.

${ }^{66}$ Buchanan, op. cit. (ref. 63), 340 .

${ }^{67}$ Trotter, op. cit. (ref. 64), 412. 
${ }^{68}$ Isaac Taylor, "A word wanted", The academy, xxvii (1885), 244. A number of other candidates were suggested in The academy beginning in March 1885. These included deprint, authordraft, partprint, exprint, overprint, by-print, transprint, and afterprint.

${ }^{69}$ A. B. Basset, "The organisation of scientific literature", Nature, xlviii (1893), 436.

${ }^{70}$ Gustaf Eneström to Poincaré, 24 May 1885 (Archives Henri Poincaré, Nancy, France).

${ }^{71}$ Poincare to Eneström, 3 June 1885 (Archives of the RSAS Center for History of Sciences, available also at the Archives Henri Poincaré (ref. 70)).

${ }^{72}$ Bather, op. cit. (ref. 38), 361. See also the Rapport sur la réforme de la bibliographie scientifique (Paris, 1895).

${ }^{73}$ A Free Lance, op. cit. (ref. 30), 4; Donnan, op. cit. (ref. 34), 436.

${ }^{74}$ Foster, "Organisation of science" (ref. 31), 563.

${ }^{75}$ To disparage the Philosophical transactions had itself become a kind of trope. See for instance Lodge, op. cit. (ref. 45), 293; A Free Lance, op. cit. (ref. 30), 6-9; and H. E. Armstrong, "Presidential address", Journal of the Chemical Society, $\operatorname{xv}$ (1894), 336-78, pp. 344-5. This questioning of the Royal Society's right to publish original scientific work represented a crucial reversal of mid-century norms, when the President of the Chemical Society, for instance, justified his society's publishing activities by contending that it did not lure authors away from publishing work that by rights belonged in the Transactions. See the "Annual report", Quarterly journal of the Chemical Society, v (1853), 153-65, p. 163.

76 "Wanted: A science reform", Chemist \& druggist, xli (1892), 583-4, p. 583.

${ }^{77}$ Michael Foster, Letter to the President presented at the Council Meeting of 5 July 1893. A copy of this letter is pasted into the Procedure Committee Minutes Book (CMB 43, Archives of the Royal Society, n.p.).

${ }_{78}^{78}$ Natural science, i (1892), 241-3, p. 242.

${ }^{79}$ See Procedure Committee Minutes (ref. 77). See also the Royal Society Council Minutes (5 July 1893).

${ }^{80}$ E.g., Buchanan, op. cit. (ref. 63), 340; Foster, op. cit. (ref. 39), 256; Lodge, op. cit. (ref. 45), 292; and Armstrong, "Presidential address" (ref. 75), 343.

${ }^{81}$ Anonymous review of A Free Lance's pamphlet in Natural science, i (1892), 242-3, p. 243.

82 "Wanted: A science reform" (ref. 76), 583. (Vincent was the founding director of the Criminal Investigation Department of the Metropolitan Police of London.)

83 "A move toward scientific socialism", Chemical world, March 1914, 67-71. The basic outlines of this debate would be repeated in the 1940s when John Desmond Bernal proposed anew a central distribution scheme for scientific papers. The main difference - besides the heightened ideological stakes of the 'Freedom in Science' battles - is that by the 1940s the crucial role of the journal in the assessment of scientific value was so well established that his proposal was greeted with near-universal alarm and apprehension by scientists and non-scientists alike.

${ }^{84}$ Henry Alfred Todd, "Cooperative bibliography", in Proceedings of the eighteenth annual meeting of the Modern Language Association of America (1900), pp. xi-xvi, p. xii.

${ }^{85}$ The one exception is the Société bibliographique, a Catholic organization that was founded to "battle against intellectual and moral depravity" through better bibliographical oversight of the press. The connection between bibliographical lists and religious censorship has its own storied history, going back at least to the sixteenth-century Index librorum prohibitorum.

${ }^{86}$ See Robert Byrnes, "The French publishing industry and its crisis in the 1890's", Journal of modern history, xxiii (1951), 232-42; and Benoit Lecoq, "Les revues", in Histoire de l'édition française, iv (Paris, 1982), 333-9.

${ }^{87}$ For details on the establishment of the first press-clipping bureau, see Anke te Heesen, Der Zeitungsausschnitt (Frankfurt, 2006), and Boris Dänzer-Kantof and Sophie Nanot, Le roman vrai de l'Argus de la presse (Paris, 2000).

${ }^{88}$ The standard Argus de la presse advertisement during the 1890s claimed to "lit, découpe et traduit tous les journaux du monde, et en fournit les extraits sur n'importe quel sujet" ; later advertisements simply stated "VOIT TOUT". See Heesen, Der Zeitungsausschnitt (ref. 87), 84-8, for more on the dream versus the reality of these services.

${ }^{89}$ Ch. Limousin, "L'éphémérographie: Bibliographie des journaux et publications périodiques", Bulletin de l'IIB, $\mathrm{v}$ (1900), 146.

${ }^{90}$ The Institut's precise name fluctuated; it was variously known as the Institut de Bibliographie Scientifique, the Institut International de Bibliographique Scientifique, and the Institut International de Bibliographie Médicale.

${ }^{91}$ Marcel Baudouin, "Le problème bibliographique", Revue scientifique, iv (1895), 708-15, p. 708.

${ }^{92}$ John Shaw Billings (1838-1913) was deputy surgeon-general and librarian of the Surgeon-General's Office (later the National Library of Medicine) until retiring in 1895 and becoming founding director of the New York Public Library. He also founded the Index-catalogue of the Library of the Surgeon-General's Office, a retrospective catalogue of medical literature. (The Index medicus was a current index.) 
${ }^{93}$ For an account of the modern history of the index card, see Markus Krajewski, Zettelwirtschaft: die Geburt der Kartei aus dem Geiste der Bibliothek (Berlin, 2002). (An English translation, Notes \& quotes: Cards, catalogs, and office efficiency, 1548-1929 is forthcoming.) For the index card's late nineteenth-century migration to Europe from the United States, see the sixth chapter.

${ }^{94}$ Baudouin "Le problème bibliographique" (ref. 91), 708-9.

${ }^{95}$ La bibliographie scientifique, i (1895), 110.

${ }^{96}$ Circulating libraries were also founded for other disciplines. A Bibliothèque Mathématique des Travailleurs, for instance, was founded in Paris in 1895. See Les tablettes du chercheur, vi (1895), 212-14.

${ }^{97}$ See the massive user survey, "La science dans les bibliothèques" published by the Revue scientifique in July-August 1905.

98 "L'Institut désire jouer, dans le domaine scientifique, le rôle dévolu dans la grande Presse à l'Agence Havas, à l'Agence Nationale, etc.", La bibliographie scientifique, ii (1896), 18.

${ }^{99}$ Bulletin des sommaires des journaux scientifiques, littéraires, financiers, i, no. 6 (1888), 44; ii, no. 13 (1889), 100; ii, no. 14 (1889), 108.

${ }^{100}$ In the early 1890s, Baudouin was a préparateur at the Faculté de Médicine in Paris. Unluckily, he is now perhaps best known as the Parisian doctor who performed a detailed medical examination of Joseph Pujol, the professional flatulist (la Pétomane).

${ }^{101}$ These included Le progrès médical, Archives provinciales de chirurgie, and the Gazette médicale de Paris.

102 "Causerie", Bulletin des sommaires, ii (1889), 100.

${ }^{103}$ See chap. 4 of Krajewski, op. cit. (ref. 93).

${ }^{104}$ E. L. Mark, "Dr. Phil. Herbert Haviland Field, 1868-1921" (Schaffhausen, 1921), 2. Field himself recounted that he had subsequently become fascinated with finding better means of locating papers in his well-trod sub-discipline. (Annotationes concilii bibliographici, iii (1907), 1.)

${ }^{105}$ Field participated in the British debates on the reform of scientific publishing that I analysed in Part I. See "An international zoological record", Nature, xlvii (1893), 606-7.

${ }^{106}$ Robert Fox, "The early history of the Société Zoologique de France", in his The culture of science in France, 1700-1900 (Aldershot, 1992).

${ }^{107}$ The Société had taken up the problem of nomenclature early in its existence, but the matter hardly progressed until Blanchard pushed it forcefully onto the agenda of the 1889 International Congress. See R. V. Melville, Towards stability in the names of animals (London, 1995).

${ }^{108}$ Gordon McOuat has published a fascinating series of essays on the history and philosophy of the connections between species, nomenclature, and cataloguing. See his "Species, rules and meaning", Studies in history and philosophy of science, xxi (1996), 473-519; and "The politics of "natural kinds", in U. Klein (ed.), Spaces of classification (Berlin, 2003), 97-114.

${ }^{109}$ For this reason, it is not surprising that Julius Victor Carus, the great figure of zoological bibliography, was also a founding member of the 5-person Nomenclature Commission.

${ }^{110}$ For Field's initial proposal, see "La réforme bibliographique", Mémoires de la Société Zoologique de France, 1894, 259-63.

${ }^{111}$ The Commission also included Baudouin, Charles-Marie Gariel, Charles Richet and Adolphe Cartaz. Their report appeared in the Bulletin de l'AFAS, lxxiii (1895), 31-9.

${ }_{112}^{11}$ Its place on the agenda just preceded the formation of the Nomenclature Commission.

${ }^{113}$ E.-L. Bouvier's "Rapport sur le projet de réforme bibliographique" was followed by the nomination of a 7-member committee. The Société was among the first to put up funds for the new Bureau, which would be directed by Field.

${ }^{114}$ Annotationes concilii bibliographici, ii (1906), 31-7.

115 "Causerie", Bulletin des sommaires, ii (1889), 100.

${ }^{116}$ None achieved total success. Limousin's enterprise eventually folded in 1903. Baudouin's Institut faired better; contemporary accounts suggest that it was a bustling enterprise, eventually becoming a joint-stock company, but it too folded in 1906. Baudouin eventually moved back to his native village in the Vendée, dedicating himself to studying its prehistory and amassing an archive of a different sort. The Concilium had the most longevity, remaining in operation until 1940.

${ }^{117}$ The name is Baudouin's own. See his "Le problème bibliographique" (ref. 91), 711.

${ }^{118}$ Despite nearly identical names, Baudouin's Institut and the Belgian Institut were distinct. On the IIB's importation of Dewey into Europe, see Rayward's Universe of information (ref. 29) and "The early diffusion abroad of the Dewey Decimal Classification: Great Britain, Australia, Europe", in G. Stevenson and J. Kramer-Greene (eds), Melvil Dewey: The man and the classification (Lake Placid, 1983), 149-73. 
${ }^{119}$ It was Field's enterprise that was most directly threatened by the Royal Society's new cataloguing venture. Their failure to find a means of combining their efforts is part of a larger story, but see the correspondence involving Field in the International Catalogue Correspondence (MS 531, Archives of the Royal Society).

${ }^{120}$ See, e.g., Robert Fox, "Science, the university, and the state in nineteenth-century France" in G. Geison (ed.), Professions and the French state, 1700-1900 (Philadelphia, 1984), 66-146; and Alan Rocke, Nationalizing science: Adolphe Wurtz and the battle for French chemistry (Cambridge, 2001).

121 "La seconde Conférence Bibliographique Internationale de Bruxelles en 1897”, Revue scientifique, 1x (1897), 236. 